Review

\title{
Cancer Immune Therapy for Philadelphia Chromosome-Negative Chronic Myeloproliferative Neoplasms
}

\author{
Morten Orebo Holmström ${ }^{1, *}$, Hans Carl Hasselbalch ${ }^{2}$ and Mads Hald Andersen ${ }^{1,3}$ \\ 1 National Center for Cancer Immune Therapy, Department of Oncology, Herlev University Hospital, \\ DK-2730 Herlev, Denmark; mads.hald.andersen@regionh.dk \\ 2 Department of Hematology, Zealand University Hospital, DK-4000 Roskilde, Denmark; \\ hkhl@regionsjaelland.dk \\ 3 Department of Immunology and Microbiology, University of Copenhagen, \\ DK-2200 Copenhagen N, Denmark \\ * Correspondence: mhol0129@regionh.dk or holmeren1@yahoo.dk; Tel.: +45-47324800; Fax: +45-47324890
}

Received: 29 May 2020; Accepted: 29 June 2020; Published: 2 July 2020

\begin{abstract}
Philadelphia chromosome-negative chronic myeloproliferative neoplasms (MPN) are neoplastic diseases of the hematopoietic stem cells in the bone marrow. MPN are characterized by chronic inflammation and immune dysregulation. Of interest, the potent immunostimulatory cytokine interferon- $\alpha$ has been used to treat MPN for decades. A deeper understanding of the anti-cancer immune response and of the different immune regulatory mechanisms in patients with MPN has paved the way for an increased perception of the potential of cancer immunotherapy in MPN. Therapeutic vaccination targeting the driver mutations in MPN is one recently described potential new treatment modality. Furthermore, $\mathrm{T}$ cells can directly react against regulatory immune cells because they recognize proteins like arginase and programmed death ligand 1 (PD-L1). Therapeutic vaccination with arginase or PD-L1 therefore offers a novel way to directly affect immune inhibitory pathways, potentially altering tolerance to tumor antigens like mutant CALR and mutant JAK2. Other therapeutic options that could be used in concert with therapeutic cancer vaccines are immune checkpoint-blocking antibodies and interferon- $\alpha$. For more advanced MPN, adoptive cellular therapy is a potential option that needs more preclinical investigation. In this review, we summarize current knowledge about the immune system in MPN and discuss the many opportunities for anti-cancer immunotherapy in patients with MPN.
\end{abstract}

Keywords: myeloproliferative neoplasms; cancer immune therapy; JAK2; CALR; cancer vaccines; neo-antigens; immunoediting; immunosurveillance

\section{Introduction}

In recent years, cancer immune therapy has received considerable attention, as this novel treatment modality can induce major responses and even cure patients with advanced cancer. In 2013, the academic journal Science designated cancer immune therapy as "breakthrough of the year", and in 2018, James P Allison and Tasuko Honjo were awarded the Nobel Prize in Physiology or Medicine for their respective discovery of the canonical immunoregulatory systems cytotoxic T-lymphocyte antigen (CTLA)-4 and programmed death receptor (PD)-1/programmed death receptor ligand (PD-L)1, and cancer immune therapy is now used with great success in the treatment of several solid cancers.

In the setting of hematological malignancies, this therapy in the form of chimeric antigen receptor (CAR) T cells and immune-checkpoint-blocking antibodies has had the greatest impact in the treatment of lymphoblastic leukemia and lymphoma [1,2]. No clinical breakthroughs have been made, however, 
in the setting of myeloid leukemia, myelodysplastic syndromes and chronic myeloproliferative neoplasms (MPN). The last group consists of heterogeneous but closely related diseases of the hematopoietic stem cells (HSC) of the bone marrow. Several studies have shown that the immune system is deranged in MPN and that the reinstatement of competent tumor immune surveillance by cancer immune therapy could potentially be used to treat this group of chronic cancer diseases. In this article, we provide a short overview of MPN and the current treatment modalities. Next, we give an overview of the immune system in MPN and describe the evidence of the aforementioned immune deregulation in MPN. In addition, we offer some perspectives on potential cancer immunotherapeutic modalities that may prove successful in the setting of MPN.

\section{The Philadelphia Chromosome-Negative MPN}

The Philadelphia chromosome-negative MPN comprise essential thrombocythemia (ET), polycythemia vera (PV) and primary myelofibrosis (PMF), and are all neoplastic diseases of the HSC. The symptoms and clinical findings in MPN patients overlap, and the diseases are sometimes difficult to distinguish from each other [3-5]. Patients with ET display an elevated amount of platelets in the peripheral blood, whereas patients with PV display an elevated red cell mass in the peripheral blood, usually in concert with leukocytosis and thrombocytosis. Both patients with ET and PV have an increased risk of thromboembolism and hemorrhage. In contrast to these hyperproliferative MPN is classical PMF-the advanced MPN disease, where patients display bone marrow fibrosis and cytopenia resulting in an increased risk of infections and hemorrhages. Patients with MPN have a significantly increased risk of acute myeloid leukemia (AML) [6]. The reported incidence of MPN varies from 1.15/100.000 to 4.99/100.000 [7], as does the reported prevalence: ET (11-42.851/100.000), PV (0.49-46.88/100.000) and PMF (1.76-4.05/100.000) [7]. Patients with MPN have a lower life expectancy than the background population [8] and have a lower quality of life compared to healthy controls $[9,10]$. However, patients with ET and PV may live for decades with their cancer disease [8].

Compared to other malignancies, the mutational landscape of MPN shows high homogeneity, as 98\% of patients with PV and 50-60\% of patients with PMF and ET harbor the Janus kinase 2 (JAK2) V617F mutation [11]. Approximately $70 \%$ of patients with wild-type (wt) JAK2 ET and wt JAK2 PMF have a mutation in exon 9 of the calreticulin $(C A L R)$ gene [12,13], and $10 \%$ harbor a mutation in the myeloproliferative leukemia protein $(M P L)$ gene [14,15]. The JAK2V617-mutation induces a loss of function of the JH2 pseudokinase domain of JAK2, rendering JAK2 in a constitutively active state, resulting in the activation of downstream signaling pathways such as signal transducer and activator of transscription (STAT)3, STAT5, PI3K and MAPK/ERK, followed by increased cell proliferation [16]. Even though the oncogenic mechanism of the CALR mutations is not fully clarified, it appears that the mutations enhance the binding of CALR to the thrombopoietin receptor (TPO-R), resulting in the activation of TPO-R and ensuing megakaryocyte proliferation and thrombocytosis [17-20].

In most countries, the mainstay treatment for ET, PV and hyperproliferative PMF is cytoreductive therapy, such as hydroxyurea (HU) or anagrelide. The former is a weak chemotherapeutic agent, whereas the latter inhibits the maturation of platelets from hyperproliferating megakaryocytes. HU has been speculated to confer an increased risk of secondary malignancies, even though such a link has not yet been clearly established [21]. Another treatment option for hyperproliferative MPN is interferon-alpha (IFN- $\alpha$ ), which can induce minimal residual disease and, in a subset of patients, normalization of the bone marrow [22]. In some patients, this normalization is sustained for years, even after the cessation of therapy [23]. The mechanisms of action of IFN- $\alpha$ have not yet been clearly established, but the drug is a potent immunostimulatory agent [24]. For several years, the treatment for hypoproliferative PMF has been supportive care (e.g., erythropoietin analogs, danazol and transfusions) but recently, the JAK1/2 inhibitor ruxolitinib has become available. As ruxolitinib is able to inhibit the activation of and thus signaling conferred by JAK1 and JAK2, the drug inhibits the aberrant JAK2-mediated signaling in MPN [25]. As the CALR and MPL mutations also rely on JAK2 to confer their oncogenic activation, ruxolitinib has an effect in patients with JAK2wt MPN too [26]. Ruxolitinib 
reduces splenomegaly and constitutional symptoms $[27,28]$ and confers a modest survival benefit for patients [29]. Still, the only curative treatment modality for MPN is allogeneic hematopoietic stem cell transplantation [30], which is only used rarely due to the high treatment-related mortality.

\section{The Immune System in MPN}

\subsection{Chronic Inflammation in MPN}

Several studies have shown that the immune system is deregulated in MPN [31]. Patients with PV and ET have elevated levels of interleukin (IL)-6, IL-8, IL-12, tumor necrosis factor (TNF)- $\alpha$ and IFN- $\gamma$ in the peripheral blood [32]. Tefferi et al. revealed deregulation in 20 of 30 analyzed cytokines in 127 PMF patients [33], and in another study, PMF patients displayed elevated levels of the inflammatory marker YKL-40 compared to healthy controls [34]. Most recently, a comprehensive cytokine profiling study has substantiated the significant role of elevated cytokines in disease phenotype and progression, providing a tool complementary to next generation sequencing in disease stratification and determination of the prognosis of patients with MPN [35]. Therefore, the marked effects of ruxolitinib on the constitutional symptoms in MPN are speculated to be conferred by the potent anti-inflammatory effects of this drug [36,37]. Several epidemiological studies have demonstrated a link between MPN and inflammatory/autoimmune diseases $[38,39]$. The evidence of cytokine derangements, chronic inflammation and an elevated risk of several inflammatory diseases in MPN suggests that MPN are an inflammatory model of human cancer development. In this model, chronic inflammation is hypothesized to induce the initial stem cell hit by inducing genomic instability and mutations, giving rise to MPN [40,41]. However, the theory of cancer-inducing inflammation is old and was already hypothesized by Virchow. Several lines of evidence show that chronic inflammation increases the risk of cancer at the inflamed site. As such, several chronic inflammatory and chronic infectious diseases have been linked to an increased risk of cancer [42]. This increased risk is believed to be mediated by mutagenic substances such as reactive oxygen species (ROS) and peroxynitrite that are produced by inflammatory cells at the inflamed site. After the initial stem cell hit, the transformed cells and tumor cells may co-exist and support the growth of one another by paracrine signaling in concert with the suppression of the tumor-specific immune response [43].

\subsection{The Immune System in MPN}

MPN are characterized by chronic inflammation, so both the cytokine environment and the immune system in general are deregulated [31]. Patients with PMF have fewer effector T-cells in the peripheral blood [44], and monocytosis is an independent adverse prognostic factor for overall survival in young patients with PMF [45] and in PV patients in general [46]. Riley et al. showed lower numbers of natural killer (NK) cells in the peripheral blood of MPN patients compared to healthy donors [47]. Regarding the number of regulatory T-cells (Treg) in MPN patients, data are conflicting, as two studies did not demonstrate any difference in peripheral blood Treg levels between MPN patients and healthy controls $[48,49]$, whereas another study showed that patients with MPN have lower numbers of circulating Treg, and this difference was applicable for patients with ET, PV and PMF compared to healthy controls [50]. Two studies have investigated the number of myeloid-derived suppressor cells (MDSC) in the peripheral blood of MPN patients. MDSC are cells of myeloid origin that emerge in almost all cancer types and are able to suppress T-cell functionality through several mechanisms such as the release of the arginine-degrading enzyme arginase-I (ARG1), ROS and prostaglandins. A detailed description of the role of MDSC in cancer has been provided by Ostrand-Rosenberg and Gabrilovich [51,52]. Interestingly, MDSC from patients with MPN have a greater inhibitory potential against autologous CD3 + T cells compared to MDSC from healthy donors [53,54], and patient peripheral blood mononuclear cells (PBMC) show higher expression of ARG1 compared to healthy donor MDSC [53]. The JAK2V617F mutation is present in cells from the lymphoid compartment in some patients [55], and we recently identified CALR mutations in lymphoid cells from several patients 
with CALR exon 9 mutations [56]. Because of the important immune-related functions of both JAK2 and CALR [57-62], functional aspects of these mutations in the lymphoid compartment seem to be implicated, but the aspects of these mutations have yet to be elucidated.

\subsection{Immune-Subversive Mechanisms in MPN}

Apart from immune dysregulation in MPN, several other factors are believed to attenuate the tumor-specific immune response. Monocytes from PMF patients produce elevated amounts of the immunoregulatory cytokine transforming growth factor-beta (TGF- $\beta$ ) [63]. In addition, patients with PV have increased levels of terminally differentiated CD8+ T cells and lower levels of naïve T-cells compared to healthy age-matched controls. They also display lower levels of stable cell surface human leukocyte antigen (HLA)-I [64].

In gene expression profiling studies, Skov et al. showed a marked dysregulation of immune-related genes in MPN. Patients with MPN exhibit downregulation of human leucocyte antigen (HLA)-I, HLA-II, and HLA-related genes-such as beta-2-microglobulin, TAP1, TAP2 and CIITA [65] - and genes related to the activation and differentiation of lymphocytes were also reported to be downregulated [66]. Furthermore, MPN patients exhibit an upregulation of IL-4, which could lead to the enhanced expression of the anti-apoptotic protein survivin [67]. Patients with PV show upregulated IL-10, a cornerstone immunoregulatory cytokine, as well as a downregulation of CD40L and FAS, implying reduced antigen-presenting cell/T-cell interaction and decreased cytotoxic T-cell killing potential [67].

Romano and coworkers recently provided a detailed overview of the functionality of the immune system in MPN [68]. The main findings were that patients with PMF display lower levels of myeloid dendritic cells (moDCs) compared to healthy donors, and that moDCs from MPN patients display a lower priming potential compared to healthy-donor moDCs. Several important facts regarding immune cell functionality in CALR-mutant MPN were identified: moDCs in CALR-mutant PMF show decreased amounts of co-stimulatory molecules, $C A L R$-mutant patients have a reduced Th1 compartment, and the Treg from patients with CALR-mutant PMF are more suppressive compared to Treg from JAK2-mutant patients and healthy donors [68]. As such, all of these findings could explain the tumor immune escape in MPN. In an elegant study, Prestipino et al. showed that JAK2V617F+ cells display increased levels of PD-L1 [69]. In a recent study, it was demonstrated that both CD4+ and CD8+ T cells, monocytes, and CD34+ hematopoietic stem cells from patients with MPN display an enhanced expression of both PD-L1 and PD-1 [70]. In addition to increased PD-1 expression, T cells from CALR-mutant patients also display increased expression of CTLA-4, and the in vitro treatment of patient T cells with PD-1- and CTLA-4-blocking antibodies enhances CALR-mutant-specific T-cell responses to CALR-mutant peptides [71]. Together, this suggests that $\mathrm{T}$ cells in patients with MPN are exhausted and thus not able to clear transformed cells, whereas the increased levels of PD-L1 on monocytes and HSC explains why T cells fail to kill the malignant cells.

Other potential but unproven immune escape mechanisms include platelet-T-cell interactions. Thrombocythemia confers a dismal prognosis in several types of solid malignancies [72]. The thrombocythemia commonly found in MPN patients has been speculated to give rise to increased cancer invasiveness and enhance the metastatic potential of second cancers through a "platelet-cancer loop" [73]. A likely explanation for this "adverse thrombocythemia" was recently providedas platelets from cancer patients bind to T cells and inhibit them through the release of TGF- $\beta$ [74]. Of interest, MPN are "megakaryocytic neoplasms" and usually exhibit thrombocythemia. As such, the thrombocythemia in patients could result in the higher binding of platelets to T cells in MPN, which, in turn, could impair T cell functionality through the binding of immunosuppressive TGF- $\beta$ to TGF- $\beta$ receptors on specific T cells.

\subsection{Immunosuppressive Mechanisms Directly Mediated by JAK2V617F or CALR Exon 9 Mutations}

The JAK2V617F mutation mediates its proliferative effects through STAT3 and STAT5 activation. Prestipino and coworkers showed that the JAK2V617F-mediated overactivation of STAT3 induces the 
enhanced expression of immunosuppressive PD-L1 on JAK2V617F-mutant cells [69]. Furthermore, the JAK2V617F mutation may modulate T-cell responses in another way by generating excessive ROS through the upregulation of Akt/PI3K, which in turn decreases levels of the ROS-converting enzyme catalase [75]. Because ROS potently inhibit $\mathrm{T}$ cell function [76,77], the excessive ROS generated by JAK2-mutant cells might dampen the JAK2V617F-specific immune response. CALR exon 9 mutations can also activate both JAK2 and PI3K/Akt [17], and CALR-mutant cells-similarly to JAK2V617F+ cells-may generate excessive amounts of ROS, thus suppressing T cell function. In addition, CALR is a chaperone important in the assembly of the HLA-I:peptide complex, and CALR-mutant cells display lower levels of HLA-I molecules [78]; however, this finding has been questioned by another study [71]. This hypothetical attenuated expression of HLA-I by CALR-mutant cells could pose an important immune escape mechanism, as the CALR mutations may potentially prevent the presentation of highly immunogenic neo-epitopes on mutant cells by the downregulation of HLA-I. Concurrently, CALR plays an important role in the generation of the cytolytic synapses of T cells [59-62], and CALR mutations have been identified in both $\mathrm{T}$ and $\mathrm{B}$ cells [56]. Thus, it is possible that cytotoxic $\mathrm{T}$ cells harboring a CALR mutation cannot exert its cytotoxic effector function.

Patients with PMF display increased levels of freely circulating CALR compared to healthy controls, but no difference in CALR levels was identified between patients with JAK2V617F+ and CALR-mutant PMF [79]. Additionally, it has been demonstrated that mutant CALR protein is not retained within the mutant cell but released into the extracellular space [80]. Garbati and coworkers showed that the stimulation of monocytes with supernatants from CALR-mutant cells enhanced the expression of IL-10 and other immunosuppressive cytokines. The authors proposed that full-length mutant CALR released from mutant cells into the supernatant is the factor responsible for the enhanced release of monocyte-derived immunosuppressive factors [81]. In concert with these findings are recently published data showing that CALR mutations may abrogate the effect of immunogenic cell death (ICD) [82]. ICD is a process where dying cells express prophagocytic surface molecules, one of the most important being CALR, thereby enhancing the DC-mediated phagocytosis of the cells, which allows for the more effective priming of $\mathrm{T}$ cells specific for antigens in the dying cell [83]. As such, it could be speculated that CALR-mutant cells release mutant CALR protein that not only induces immunosuppression through the stimulation of monocytes but also prevents the effective phagocytosis of malignant cells, hence preventing the proper priming of T cells specific for CALR-mutant epitopes, which in total would negate the effect of immunogenic cell death. Figure 1 summarizes some of the proposed immune escape mechanisms in MPN, and Table 1 provides a schematic overview of these.

Table 1. Immune-suppressive mechanisms identified in myeloproliferative neoplasms (MPN). Primary myelofibrosis (PMF), natural killer cells (NK cells), myeloid derived suppressor cells (MDSC), human leucocyte antigen (HLA), polycythemia vera (PV).

\begin{tabular}{lcc}
\hline \multicolumn{1}{c}{ Escape Mechanism } & MPN Type & Reference \\
\hline Fewer effector T cells in peripheral blood & PMF & {$[40]$} \\
\hline Fewer NK cells in peripheral blood & All MPN & {$[43]$} \\
\hline Elevated numbers of MDSC in peripheral blood & All MPN & {$[47,48]$} \\
\hline Higher inhibitory potential of MDSC in peripheral blood & All MPN & {$[47]$} \\
\hline Elevated TGF $\beta$ production by bone-marrow-derived monocytes & PMF & {$[57]$} \\
\hline $\begin{array}{l}\text { Lower levels of naïve T-cells and higher levels of terminally } \\
\text { differentiated effector T-cells }\end{array}$ & PV & {$[58]$} \\
\hline $\begin{array}{l}\text { Lower levels HLA-I on monocytes } \\
\text { Lower levels of HLA-I on mutant cells }\end{array}$ & PV & {$[58]$} \\
\hline $\begin{array}{l}\text { Deregulation of genes related to antigen processing and activation } \\
\text { as well as immune cell activation and inflammation }\end{array}$ & All MPN & {$[59-61]$} \\
\hline $\begin{array}{l}\text { Lower number of myeloid dendritic cells and lower priming } \\
\text { potential of myeloid dendritic cells }\end{array}$ & $\begin{array}{c}\text { PMF (lower number of myeloid } \\
\text { dendritic cells), all MPN }\end{array}$ & {$[62]$} \\
\hline
\end{tabular}


Table 1. Cont

\begin{tabular}{lcc}
\hline \multicolumn{1}{c}{ Escape Mechanism } & MPN Type & Reference \\
\hline Reduced Th1 compartment and more suppressive regulatory T-cells & CALR-mutant MPN & {$[62]$} \\
\hline Increased expression of PD-L1 on JAK2V617F ${ }^{+}$cells & $J A K 2 V 617 F^{+}$MPN & {$[63]$} \\
\hline $\begin{array}{l}\text { Increased expression of PD-1 and PD-L1 on CD4+ and CD8 }{ }^{+} \text {T-cells, } \\
\text { monocytes and CD34 }{ }^{+} \text {hematopoietic stem cells }\end{array}$ & All MPN & {$[64]$} \\
\hline $\begin{array}{l}\text { Increased expression of PD-1 and CTLA-4 on T cells } \\
\text { Overproduction of reactive oxygen species }\end{array}$ & All MPN & {$[65]$} \\
\hline $\begin{array}{l}\text { Overproduction of IL-10 and additional immunosuppressive } \\
\text { cytokines by monocytes }\end{array}$ & CALR-mutant MPN & {$[69]$} \\
\hline Abrogation of immunogenic cell death & CALR-mutant MPN & {$[75]$} \\
\hline
\end{tabular}

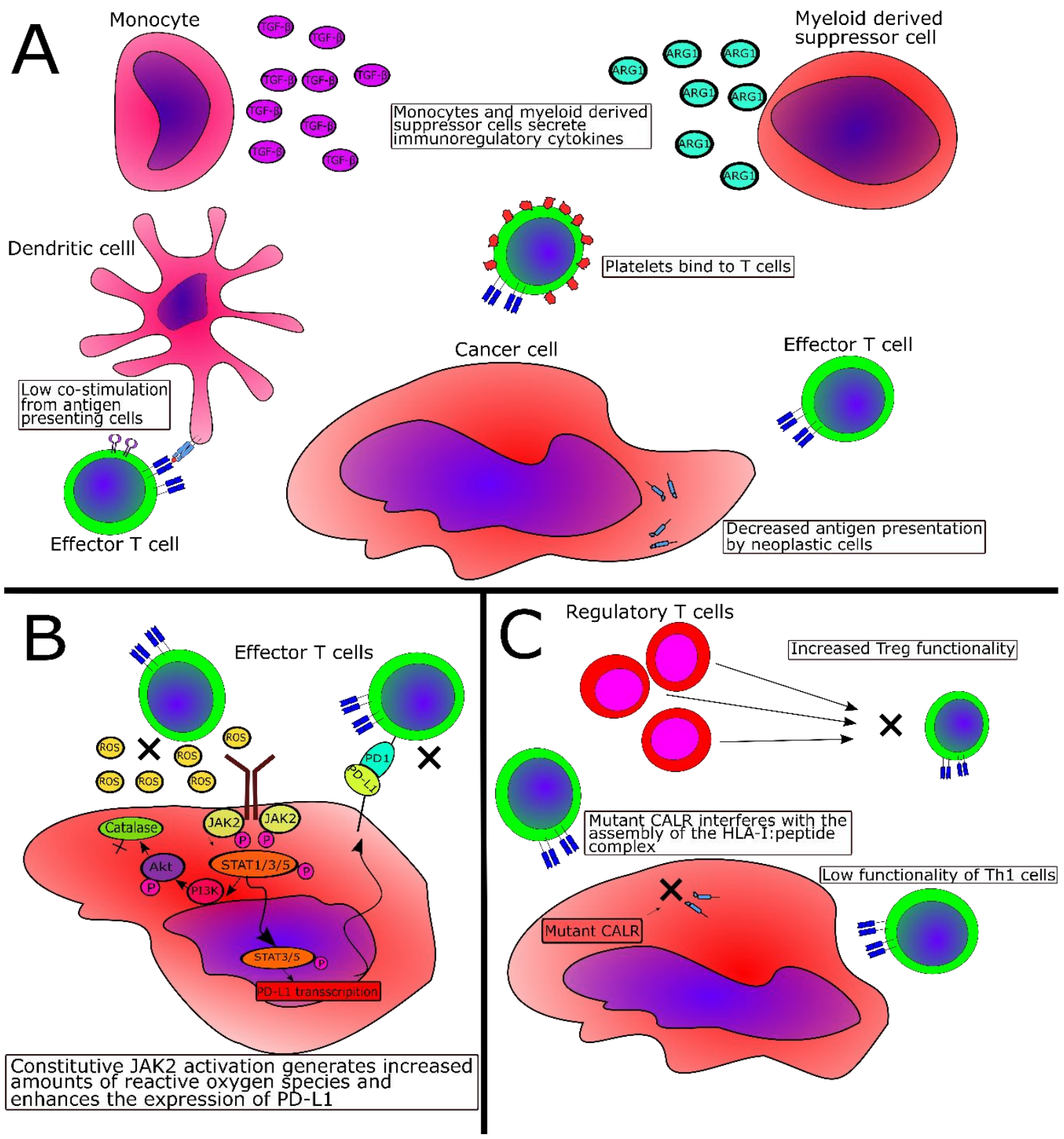

Figure 1. Suggested immune escape mechanisms in MPN. (A). Escape mechanisms that are shared between all MPN types, starting from the top and moving clockwise. Myeloid cells such as monocytes and myeloid-derived suppressor cells secrete TGF- $\beta$ and ARG1, respectively. These proteins are highly 
immunosuppressive to $\mathrm{T}$ cells and thus induce immune suppression in the tumor microenvironment (TME). Platelets, which suppresses $\mathrm{T}$ cell reactivity, are released from the hyperproliferating megakaryocytes and bind to T cells, thereby suppressing tumor-specific T cells. Both JAK2- and CALR-mutant cells express lower levels of HLA-I molecules, resulting in decreased antigen presentation to $\mathrm{T}$ cells, thus facilitating tumor immune escape. Antigen-presenting cells express lower levels of costimulatory molecules, thus decreasing the priming of T cells. (B). Escape mechanisms that are employed, especially in JAK2-mutant MPN. The JAK2V617F mutation induces the activation of STAT1/3/5, whichh increases the activity of PI3K and Akt, thereby lowering the levels of the ROS-converting enzyme catalase. This results in increased levels of ROS in the TME, which decreases $\mathrm{T}$ cell reactivity. The JAK2V617F mutation induces the activation of STAT3/5, which enhances the transcripition of PD-L1, which is expressed on tumor cells, resulting in the anergy/exhaustion of activated PD-1-expressing tumor-specific T cells. (C). Escape mechanisms that are employed, especially in CALR-mutant MPN, starting from the top. Regulatory T-cells (Treg) from patients with CALR-mutant MPN are more suppressive than Treg from healthy donors. As the calreticulin protein is an important component in the assembly of the HLA-I:peptide complex, the CALR mutations were speculated to attenuate the expression of antigens on HLA-I molecules, which has now been shown [78]. Effector T-cells from patients with CALR-mutant MPN are less functional than effector T-cells from healthy donors.

\subsection{Evidence of Tumor Immne Escape in MPN}

These findings suggest that the immune system is dysregulated in MPN and that MPN develops and evolves because of tumor immune evasion. Supporting this notion is the fact that even though CALR mutations are highly immunogenic [84] and patient $\mathrm{T}$ cells are highly reactive to the mutations [85], $C A L R$-mutant cells in patients escape immune-mediated elimination. Interestingly, compared to patients with early MPN (ET), patients with advanced MPN (PMF) have fewer and weaker T-cell responses to mutant CALR epitopes [84]. This finding fits into the general concept of tumor-specific immune responses, which stipulates that the immune system in patients with advanced cancer is exhausted and hyporeactive [86]. As the CALR mutations are cancer-specific mutations, healthy donor $\mathrm{T}$ cells are not expected to display any reactivity against mutant CALR epitopes. However, most surprisingly, we have shown that healthy donors harbor T cells specific to mutant CALR epitopes. These responses are stronger and more frequent than in patients with CALR-mutant MPN, and healthy donor $\mathrm{T}$ cells specific to the mutant CALR epitopes are memory T-cells [87]. This implies that specific $\mathrm{T}$ cells in healthy donors are antigen experienced, i.e., they have been challenged with mutant CALR epitopes previously. An explanation for this could be that healthy individuals allegedly acquire a CALR exon 9 mutation, but given the high immunogenicity of the mutations, the immune system clears all the mutant cells, and the generation of T-cell memory specific to the mutant CALR ensues. The isolation, using tetramers, of CALR-mutant-specific T cells from healthy donor PBMC offers further evidence for this concept [88]. The high frequency of CALR-mutant-specific immune responses in healthy donors suggests that only a very low proportion of healthy donors harbor CALR exon 9 mutations. This was recently proved in a Danish population-based study where 19,958 individuals were analyzed for the occurrence of the JAK2V617F and CALR exon 9 mutations. Interestingly, $3.1 \%$ of the total population were JAK2V617F+, whereas only $0.16 \%$ harbored a CALR mutation, giving a ratio of JAK2V617F to CALR-mutation of 19:1 [89]. By contrast, the ratio is only 5.6:1 in patients [89]. This suggests that healthy donors clear the CALR-mutant cells before they establish and expand in the bone marrow. After a median follow up of 6.2 years, four of the CALR-mutant healthy donors identified in the above-mentioned study underwent full medical examination including bone marrow biopsy to clarify if they had developed overt CALR-mutant MPN [90]. Interestingly, none of the healthy donors had developed MPN, and all the donors displayed strong T-cell responses to several CALR-mutant epitopes [90]. Taken together, these data support the hypothesis of cancer immunoediting $[86,91]$ in MPN: healthy donors display T-cell memory to mutant CALR epitopes (elimination) [87], healthy donors with CALR-mutant cells in the peripheral blood show strong T-cell responses to CALR mutations (editing) [90], and patients with overt CALR-mutant MPN show weaker 
and less frequent CALR-mutant-specific immune responses compared to healthy donors (escape) [84] (Figure 2). Giving impetus to the notion of tumor immune escape in MPN, it has been demonstrated that patients with MPN have an increased risk of several cancers both before and after the diagnosis of MPN [92-94].

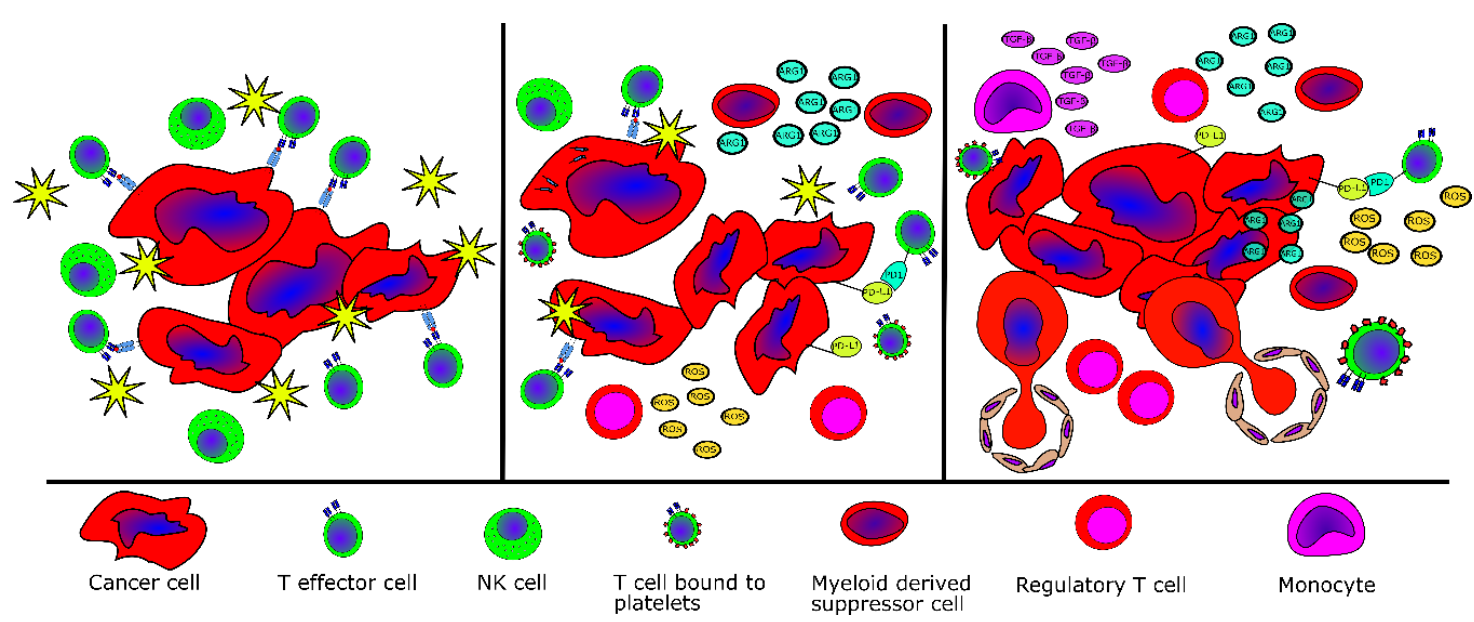

Figure 2. The disease continuum in MPN related to tumor elimination, equilibrium and escape. Left panel. The neoplastic cells are cleared by effector immune cells-T cells and NK cells. Middle panel. The immune system cannot clear neoplastic cells completely because immunosuppressive cells have now entered the tumor microenvironment and the cancer cells themselves employ immunosuppressive mechanisms. In MPN, this disease stage would be essential thrombocythemia (ET), polycythemia vera (PV) or prefibrotic/early myelofibrosis. Right panel. The immune system cannot prevent the evolution and metastasis of the malignant cells because the bone marrow is flooded with immunosuppressive cytokines such as IL-10 and ARG1 in addition to ROS released from JAK2-mutant cells. In MPN, this disease stage would be advanced myelofibrosis.

\section{Potential Cancer Immune Therapeutic Strategies for MPN}

\subsection{The Role of IFN- $\alpha$ in MPN}

In light of the above, the reinstatement of effective tumor immune surveillance seems to be an intriguing treatment option for MPN. IFN- $\alpha$ has been used to treat MPN and other malignancies for decades [95], and the mechanism of action is speculated to be its potent immunostimulatory effects [24]. IFN- $\alpha$ enhances antigen presentation, cross-priming, the maturation of dendritic cells, and the cytotoxic capabilities of cytotoxic T-lymphocytes and NK cells and suppresses the inhibitory capacity of MDSC and Treg. Data from murine studies indicate that type I interferons are responsible for the effects of anthracyclines, cyclophosphamide, radiotherapy, immune checkpoint inhibitors and allogeneic hematopoietic stem cell transplantation [95-99]. As such, the treatment of MPN with IFN- $\alpha$ probably partially reinstates otherwise-defective tumor immune surveillance, as IFN- $\alpha$ can induce a complete hematological response and significantly reduce both the JAK2-mutated [100] and CALR-mutated allele burden [101,102]. Moreover, a subset of patients experience normalization of the bone marrow and prolonged hematological responses for years, even after cessation of IFN- $\alpha$ therapy [23]. This effect suggests that IFN- $\alpha$ enhances the immune response against the malignant cells. Riley et al. demonstrated that treatment with IFN- $\alpha$ resulted in marked alterations in the immune phenotype of patients with MPN, further supporting this notion [47,49,103]. Additionally, treatment with IFN- $\alpha$ enhances the expression of both class I and class II HLA genes, implying that IFN- $\alpha$ not only potentiates immune effector cells but also sensitizes the target cells to immune-mediated destruction [104]. Another study on circulating Treg in IFN- $\alpha$-treated patients showed an increase in circulating Treg after therapy [105]. Taken together, these studies suggest that treatment with 
IFN- $\alpha$ might generate an effective anti-tumor immune response by inducing alterations in the immune phenotype and enhancing antigen presentation by malignant cells.

\subsection{Recognition of Neoplastic Cells Through Antigen Recognition by T cells}

Cancer immune therapy exploits the immune-mediated recognition of malignant cells, and this recognition depends mainly on the recognition of tumor antigens by $\mathrm{T}$ cells. There are several types of tumor antigens that may be recognized by $\mathrm{T}$ cells [106]. Generally, there are two classes of antigens that may be targeted by the immune system-self antigens and non-self antigens. One class of self antigens are so-called overexpressed antigens, which are expressed by healthy cells but overexpressed by neoplastic cells (e.g., HER2/Neu in several epithelial tumors and WT1 in AML). Another class of self antigens are differentiation antigens, which are only expressed by a very limited class of cells and by tumor cells (e.g., melanoma antigen recognized by T-cells (MART) that isexpressed by melanocytes and in melanoma). The cancer germline antigens (CGA), which are also called cancer testes antigens, are another type of self antigens that are expressed only by cancer cells or by cells in immunoprivileged tissues. The CGA are believed to be more immunogenic than the two other types of self antigens, as high-affinity CGA-specific T-cells have a lower chance of being deleted during the development of central tolerance [106]. Non-self antigens include viral antigens, which are highly immunognenic due to their non-human origin. The last type of non-self antigens are the so-called neo-antigens, which arise from acquired somatic mutations in cancer cells. These antigens are of great interest as targets for cancer immune therapy and are belived to have superior immunogenic potential compared to the other types of antigens. This is explained by the fact that neo-antigen-specific T-cells are not deleted during the development of central tolerance [107], and enhancing the neo-antigen-specific immune response through cancer immune therapy such as therapeutic cancer vaccination is an intriguing treatment option.

\subsection{Cancer Immune Therapy for MPN-Targeting the Neoantigens}

However, one inherent problem with targeting specific neoantigens through, for example, therapeutic cancer vaccines is that somatic mutations vary both between patients and between different cancers, thereby resulting in a vast plethora of different neo-antigens that are shared neither between patients nor diseases. As such, one would need to develop personalized cancer vaccines through the sequencing of the mutatonome of each patient-a feat that is possible but comes at a high cost. However, in MPN, there is no such need to target personal neo-antigens as $80-90 \%$ of patients harbor either the JAK2V617F or CALR mutations. Additionally, we recently reported that the immune system can selectively target cells carrying the JAK2V617F and CALR exon 9 mutations $[84,85,108]$. As noted above, it seems likely that patients with CALR-mutant MPN have developed disease because of tumor immune escape. The reinstatement of a competent anti-tumor immune response by therapeutic cancer vaccination might result in tumor cell clearance. As such, therapeutic cancer vaccination targeting the driver mutations in MPN may be a potential new treatment modality. For this reason, we have finalized a phase I clinical vaccination trial with a CALR-mutant epitope for patients with CALR-mutant MPN (NCT03566446), and clinical, molecular and immunological analyses are ongoing. Just recently, using in silico prediction analyses, Schischlik and colleagues showed that both the CALR and MPL mutations generate neo-antigens that may bind to common HLA-I molecules, and additionally showed that the SF3B1 mutations that are identified occasionally in MPN may be a rich source of neo-antigens that may be targeted by cancer immune therapy [109]. In this conjuncture, it would be worthwhile to investigate the frequency of certain HLA types in patients with CALR-mutant MPN, as it has been demonstrated that certain HLA types are underrepresented in cancers with immunogenic driver mutations. Patients with HLA-A3 and HLA-B8 and, especially, patients co-expressing these HLA types are underrepresented in patients with $B C R-A B L+$ chronic myeloid leukemia [110], and HLA-B*07, $B^{*} 18$ and $B^{*} 40$ are underrepresented in patients with nucleophosmine- 1 mutant AML [111]. As both of these mutations generate immunogenic neo-antigens [112,113], it is speculated that patients with the 
above-mentioned HLA types process and present highly immunogenic epitopes on transformed cells, thus facilitating immune-mediated tumor rejection.

\subsection{Targeting of Immunoregulatory Mechanisms in MPN}

Therapeutic cancer vaccination against the JAK2V617F and CALR exon 9 driver mutations is likely to induce immune responses. However, the immune dysregulation in MPN could potentially prevent tumor-specific immune responses and negate any clinical effect of vaccines. As such, targeting regulatory mechanisms in the tumor microenvironment may also be important. PD-1 is a key regulatory surface molecule that delivers inhibitory signals to maintain $\mathrm{T}$ cells' functional silence against their cognate antigens [114]. The discovery of how PD-1 on T cells binds to PD-L1 on tumor cells or other cells in the tumor microenvironment has increased our understanding of how tumors that are flooded with tumor-infiltrating lymphocytes evade immune-mediated destruction [115]. PD-1 is expressed by activated T cells, and the binding of PD-1 to PD-L1+ cells in the tumor microenvironment renders the $\mathrm{T}$ cell anergic. This phenomenon has been exploited clinically by the invention of PD-1-blocking antibodies, which block the PD-1/PD-L1 interaction. Treatment with these immune-checkpoint-blocking antibodies has shown outstanding results in a variety of solid tumors, $[116,117]$ and naturally, the PD-1-blocking antibodies have been tested in hematological cancers. The compound has shown remarkable clinical effects in the treatment of relapsed/refractory classical Hodgkin lymphoma [118]. Results from clinical trials with other hematological cancers have been less promising, albeit some studies suggest that PD-1 blockade may be more efficacious in cancers with high PD-L1 expression. As such, patients with activated B-cell (ABC)-subtype diffuse large B cell lymphoma (DLBCL) obtain more benefit from PD-1 blockade than patients with germinal center B-cell (GCB)-subtye DLBCL, which could be due to the increased expression of PD-L1 in ABC-subtype DLBCL [119]. Hence, an increased expression of PD-L1 by tumor cells could be a predictive biomarker of PD-1 blockade sensitivity. However, clinical trials with PD-1 blockers in patients with multiple myeloma (MM) have partially contradicted this notion. Myeloma cells express increased levels of PD-L1 [120], and as such, PD-1/PD-L1-targeting therapy should be ideal for patients with MM, but PD-1 blockade has not displayed any relevant clinical effect in MM [119]. PD-1-blocking antibodies have been tested in myelodysplastic syndrome (MDS) and AML. The rationale for this is the fact that patient peripheral blood T cells express higher levels of PD-1 at relapse [121], and treatment with with clinically approved hypomethylating agents such as 5-azacytidine and 5-aza-2'deoxycitidine increases the expression of PD-L1 on transformed cells and PD-1 on T cells [122,123]. PD-1-blocking antibodies, especially in combination with hypomethylating agents, have shown promising results in relapsed/refractory AML, with an overall response rate of 33\% [124]. Taking the above into account, the linical testing of PD-1-blocking antibodies in MPN seems highly relevant given the fact that the JAK2V617F mutation enhances the expression of PD-L1 on transformed cells [69]. Taking the increased risk of autoimmune disease in patients with MPN into account, one needs to carefully consider the use of PD-1-blocking antibodies, as treatment with these frequently results in the emergence of autoimmune phenomena [125]. To date, only one study is evaluating the clinical efficacy of immune checkpoint inhibitors in patients with MPN (NCT03065400), but no clinical results have been reported at the time of the writing of this paper. T cells from one patient included in the above-mentioned trial showed enhanced reactivity to $C A L R$-mutant epitopes after treatment in vivo and in vitro with PD-1-blocking antibodies [71], thus supporting the idea of enhancing T-cell responses in patients with MPN by immune checkpoint inhibitors.

Interestingly, the immune system itself can target regulatory cells, and naturally occurring $\mathrm{T}$ cells specific to epitopes from pivotal immune regulatory proteins such as indoleamine 2,3-dioxygenase, PD-L1, PD-L2 and ARG1 have been described in cancer patients [126-129]. The PD-L1-peptide co-stimulation of T-cell cultures in vitro increases the immune response against viral antigens [130] and enhances the immunogenicity of a dendritic cell-based cancer vaccine [131]. As such, the vaccination of cancer patients with epitopes from these immunoregulatory proteins is likely to induce the formation 
of anti-regulatory T cells, which would enhance the tumor-specific immune response [132]. As noted above, patients with MPN have increased levels of the immunoregulatory proteins ARG1 and PD-L1 [53,69]. Of interest, patients with MPN have frequent and strong T-cell responses against both of these regulatory proteins $[133,134]$, and vaccination with these epitopes could potentially target immunoregulatory mechanisms and neoplastic cells in MPN (Figure 3). Patients with non-advanced MPN (e.g., ET) have stronger and more frequent responses compared to patients with advanced MPN (e.g., PMF) [133,134]. These data are in line with the notion that patients with non-advanced cancer have a more potent tumor-specific immune response [86]. This pattern has also been demonstrated clinically: patients with non-advanced cancer have the best clinical responses to therapy $[135,136]$. In the setting of MPN, the implication is that patients with ET and PV are more likely to have a response to therapeutic cancer vaccination. By contrast, patients with advanced PMF should be considered for other, more advanced treatment modalities. We believe that the immune responses elicited by vaccinations with the JAK2-mutated or CALR-mutated antigens may be enhanced by vaccination against one or more immunoregulatory mechanisms, such as PD-L1 and ARG1. As the expression of the cornerstone immunoregulatory proteins PD-L1 and ARG1 is increased in MPN, we speculate that vaccination against both of these will enhance the anti-tumor immune response in patients, and we have consequently launched a phase I/II clinical vaccination trial with PD-L1- and ARG1-derived epitopes in patients with MPN (NCT04051307).

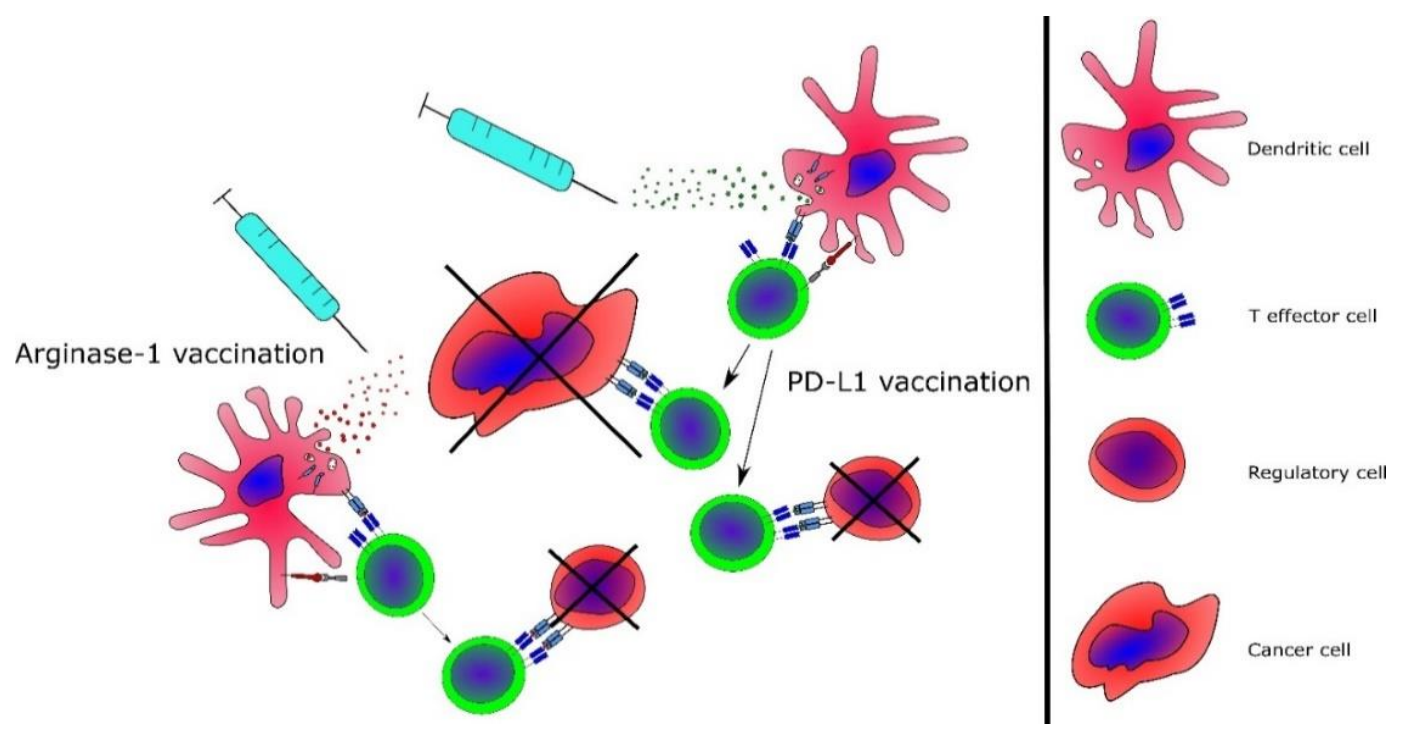

Figure 3. Therapeutic cancer vaccination targeting immunosuppressive mechanisms in MPN. Left. Vaccination with arginase-1 (ARG1)-derived epitopes will enhance the ARG1-specific T-cell response, leading to the recognition and killing of ARG1-producing cells and resulting in decreased amounts of ARG1 in the tumor microenvironment. Right. Vaccination with PD-L1-derived epitopes will induce a T-cell response against regulatory cells and against JAK2V617F-mutant cells.

\subsection{Advanced Cancer Immune Therapeutic Strategies for MPN}

For patients with advanced myelofibrosis, peptide vaccination is not believed to induce an effective anti-tumor immune response, and patients with advanced PMF exhibit both functional and quantitative immune defects, as described above. As such, another advanced, yet feasible, treatment modality for these patients would be adoptive T-cell therapy, in which tumor-reactive autologous $\mathrm{T}$ cells are infused into the patient. These tumor-reactive $T$ cells can be grown from tumor-infiltrating lymphocytes (TIL) [137]. Obtaining TIL from patients with PMF would require obtaining bone marrow cells, which is not possible in these patients because of the fibrotic marrow (i.e., "dry tap"). However, it is possible to expand a T-cell culture specific for a given tumor-specific antigen (e.g., JAK2V617F), clone the JAK2V617F-specific T-cell receptor (TCR) and transduce the TCR into autologous T cells. 
These cells could then be expanded and reinfused into the patient [137]. The development of such treatment modalities is in the early stages, but the possibilities are intriguing because patients with advanced MPN could possibly reap great benefits from this treatment. However, the potential of off-target effects of the TCR of interest requires close assessment. Especially in the setting of the JAK2V617F mutation, which is a single amino acid substitution, cross-reactivity with the wt epitope is a risk and could result in deleterious side effects.

The treatment of patients with acute lymphoblastic leukemia and non-Hodgkin lymphoma with CART and bispecific T-cell engagers (BiTE) has shown remarkable results, with overwhelming response rates in heavily pre-treated patients $[1,138]$. These modalities target $C D 19$, which is a surface molecule commonly expressed in several B-cell malignancies, and treatment with CD19-specific CART results in chronic B-cell aplasia in a substantial proportion of patients due to the cytotoxic killing of both tumor cells and B-cell precursors. Although this B-cell aplasia is problematic, patients can live with this condition. However, the treatment of MPN with CART and BiTE is challenging because no surface antigen has been shown to be genuinely expressed by the neoplastic cells. Targeting hematopoietic stem cell markers expressed by malignant cells in MPN, such as CD33 and CD34, would likely result in the killing of both neoplastic and normal hematopoietic stem cells and is thus precluded. Mutant CALR is expressed on the plasma membrane and binds the thrombopoietin receptor [17]. If this binding of mutant CALR to the thrombopoietin receptor is stable, the possibility of CALR-mutant-specific monoclonal antibodies might be worth exploring. An illustration of the potential different cytotherapeutic modalities for MPN is provided in Figure 4.

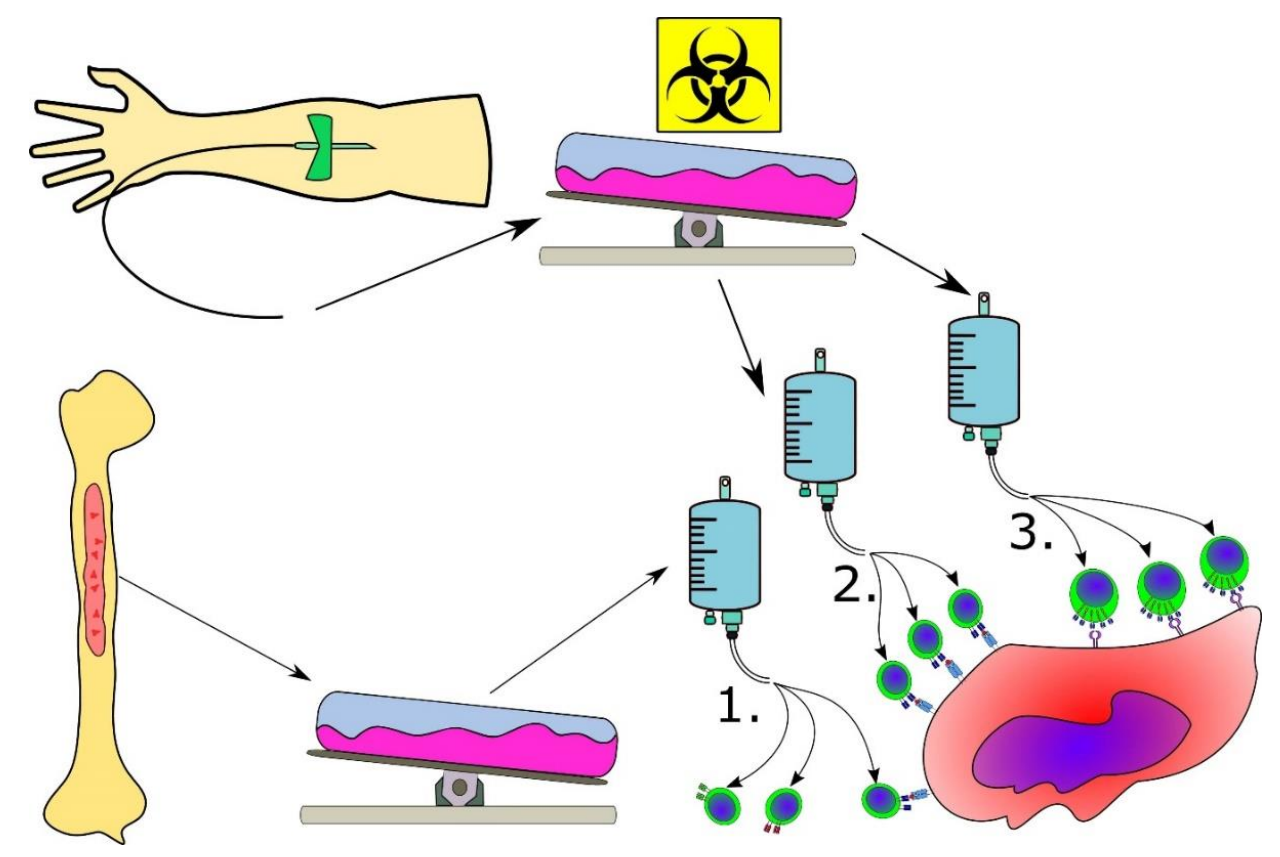

Figure 4. Cytotherapeutic modalities for MPN. (1). Tumor-infiltrating lymphocytes (TIL) are isolated from the bone marrow of the patient, expanded and reinfused into the patient. Only some of the TIL are specific to the neoplastic cells in the bone marrow. These are displayed by the $\mathrm{T}$ cell with the blue T-cell receptor (TCR), which is the only TCR specific for the antigen of interest. (2). Peripheral blood mononuclear cells (PBMCs) are isolated from the peripheral blood of the patient, and the PBMCs are transduced or transfected in bioreactors to express a TCR specific for an antigen expressed by the cancer cell. This is displayed by all the T cells that have a TCR specific for the antigen of interest (blue TCR). (3). PBMC are isolated from the peripheral blood of the patient and are transduced with DNA that encodes a chimeric antigen receptor (CAR). This CAR combines the promiscuity of the B cell receptor (no need for presentation on HLA molecules) with the power of the TCR, allowing the CAR T-cell to be activated and initiate cytotoxic killing upon binding to a surface molecule on the target cells. In the setting of MPN, this antigen expressed on the surface of the cell could be mutant CALR. 


\subsection{Combinatorial Strategies Involving Cancer Immune Therapy}

Cancer vaccines represent a promising means of eliminating minimal residual disease without inducing toxicity and secondary malignancies [139]. However, to date they have largely failed to demonstrate a significant improvement of patient outcomes, probably reflecting the ability of malignant cells to suppress the function of the induced immune cells. As suggested above, co-vaccination against ARG1 and/or PD-L1 may be synergistic. Another exciting approach is combining it with checkpoint-blocking antibodies directed against the PD-1/PD-L1 pathway. In practice, antibodies that target the inhibitory checkpoints elicit impressive, dynamic and durable tumor regression and boost anti-cancer immune responses. Given the biological effects of IFN- $\alpha$, the combination of IFN- $\alpha$ with vaccination seems logical. Vaccination would prime the immune system to target cells carrying the mutated antigen, and IFN- $\alpha$ would further enhance the induced anti-cancer immune response to eliminate malignant cells. Another intriguing treatment modality would be to exploit ICD, a form of regulated cell death that can activate the adaptive immune response and induce an immune response against antigens from the dead cells $[83,140]$. Certain chemotherapeutic agents and radiation induce ICD, and their clinical effects are speculated to depend mainly on ICD. This association may explain the abscopal influence of radiation therapy in which tumor masses outside the radiation field shrink after radiation therapy [83]. One of the hallmarks of ICD is the emergence of CALR on the plasma membrane. Obeid et al. showed that radiation or treatment with anthracyclines induces the surface exposure of CALR and that this exposure leads to the enhanced phagocytosis of tumor cells by dendritic cells. Furthermore, CALR-mediated phagocytosis enhances IFN- $\gamma$ release in tumor-draining lymph nodes, and radiation and anthracycline therapies appear to depend on an intact T-cell response because T-cell-depleted mice do not respond to treatment [141,142]. However, the study by Liu et al. mentioned above poses the idea that the induction of ICD in patients with CALR-mutant MPN will not induce a tumor-specific immune response [82]. Hence, the freely circulating mutant CALR produced by transformed cells will be phagocytosed by APCs and, consequently, abrogate thephagocytosis of transformed cells by the APC. However, the induction of ICD in patients with JAK2V617F ${ }^{+} \mathrm{MPN}$ might still seem as an option worth investigating, especially as the JAK2V617F-mutation is not nearly as immunogenic as the $C A L R$ exon 9 mutations. As such, an enhanced tumor specific immune response to $J A K 2 \mathrm{~V}_{6} 17 \mathrm{~F}^{+}$cells through ICD might be what is needed to induce a $J A K 2 \mathrm{~V} 617 \mathrm{~F}^{+}$-specific immune response.

\section{Conclusions}

MPN are associated with a deregulation of the immune system, and cancer immune escape is likely an important factor in the development and evolution of the disease. However, this immune dysregulation could be reverted by several therapeutic options to reinstate tumor immune surveillance. Vaccination with JAK2-mutant- and CALR-mutant-derived peptides will probably induce tumor-specific immune responses that will be further enhanced by co-vaccination with anti-regulatory epitopes, such as PD-L1- and ARG1-derived epitopes. Other therapeutic options that could be used with therapeutic cancer vaccines are immune checkpoint-blocking antibodies and IFN- $\alpha$. For patients with more advanced MPN, adoptive T-cell therapy with TIL or TCR-transduced T cells is a potential option but needs more preclinical investigation. The lack of proper extracellular targets for CART and BiTEs make these two otherwise-intriguing treatment modalities unlikely candidates.

Funding: The writing of this paper was partially funded by a grant from the Danish Cancer Society (Kræftens Bekæmpelse) to Hans Hasselbalch, grant no. R149-A10159-B120.

Conflicts of Interest: Morten Orebo Holmström, Hans Carl Hasselbalch and Mads Hald Andersen have filed a patent regarding the CALR Exon 9 mutations and JAK2V61F mutation as a target for cancer immune therapy. The patent has been transferred to University Hospital Zealand, Zealand Region and Copenhagen University Hospital at Herlev, Capital Region according to Danish Law concerning inventions made at public research institutions. 


\section{References}

1. Park, J.H.; Rivière, I.; Gonen, M.; Wang, X.; Sénéchal, B.; Curran, K.J.; Sauter, C.; Wang, Y.; Santomasso, B.; Mead, E.; et al. Long-Term Follow-up of CD19 CAR Therapy in Acute Lymphoblastic Leukemia. N. Engl. J. Med. 2018, 378, 449-459. [CrossRef] [PubMed]

2. Neelapu, S.S.; Locke, F.L.; Bartlett, N.L.; Lekakis, L.J.; Miklos, D.B.; Jacobson, C.A.; Braunschweig, I.; Oluwole, O.O.; Siddiqi, T.; Lin, Y.; et al. Axicabtagene Ciloleucel CAR T-Cell Therapy in Refractory Large B-Cell Lymphoma. N. Engl. J. Med. 2017, 377, 2531-2544. [CrossRef] [PubMed]

3. Campbell, P.P.J.; Green, A.A.R. The Myeloproliferative Disorders. N. Engl. J. Med. 2006, 355, $2452-2466$. [CrossRef] [PubMed]

4. Spivak, J.L. Myeloproliferative Neoplasms. N. Engl. J. Med. 2017, 376, 2168-2181. [CrossRef] [PubMed]

5. Levine, R.L.; Gilliland, D.G. Myeloproliferative disorders. Blood 2008, 112, 2190-2198. [CrossRef] [PubMed]

6. Björkholm, M.; Derolf, Å.R.; Hultcrantz, M.; Kristinsson, S.Y.; Ekstrand, C.; Goldin, L.R.; Andreasson, B.; Birgegård, G.; Linder, O.; Malm, C.; et al. Treatment-related risk factors for transformation to acute myeloid leukemia and myelodysplastic syndromes in myeloproliferative neoplasms. J. Clin. Oncol. 2011, 29, 2410-2415. [CrossRef]

7. Anderson, L.A.; McMullin, M.F. Epidemiology of MPN: What Do We Know? Curr. Hematol. Malig. Rep. 2014, 9, 340-349. [CrossRef]

8. Tefferi, A.; Guglielmelli, P.; Larson, D.R.; Finke, C.; Wassie, E.A.; Pieri, L.; Gangat, N.; Fjerza, R.; Belachew, A.A.; Lasho, T.L.; et al. Long-term survival and blast transformation in molecularly annotated essential thrombocythemia, polycythemia vera, and myelofibrosis. Blood 2014, 124, 2507-2513. [CrossRef]

9. Geyer, H.L.; Scherber, R.M.; Dueck, A.C.; Kiladjian, J.J.; Xiao, Z.; Slot, S.; Zweegman, S.; Sackmann, F.; Fuentes, A.K.; Hernández-Maraver, D.; et al. Distinct clustering of symptomatic burden among myeloproliferative neoplasm patients: Retrospective assessment in 1470 patients. Blood 2014, 123, 3803-3810. [CrossRef]

10. Emanuel, R.M.; Dueck, A.C.; Geyer, H.L.; Kiladjian, J.J.; Slot, S.; Zweegman, S.; Te Boekhorst, P.A.W.; Commandeur, S.; Schouten, H.C.; Sackmann, F.; et al. Myeloproliferative neoplasm (MPN) symptom assessment form total symptom score: Prospective international assessment of an abbreviated symptom burden scoring system among patients with MPNs. J. Clin. Oncol. 2012, 30, 4098-4103. [CrossRef]

11. Kralovics, R.; Passamonti, F.; Buser, A.A.S.; Teo, S.-S.; Tiedt, R.; Passweg, J.R.J.; Tichelli, A.; Cazzola, M.; Skoda, R.C.R. A Gain-of-Function Mutation of JAK2 in Myeloproliferative Disorders. N. Engl. J. Med. 2005, 352, 1779-1790. [CrossRef] [PubMed]

12. Klampfl, T.; Gisslinger, H.; Harutyunyan, A.S.; Nivarthi, H.; Rumi, E.; Milosevic, J.D.; Them, N.C.C.; Berg, T.; Gisslinger, B.; Pietra, D.; et al. Somatic mutations of calreticulin in myeloproliferative neoplasms. N. Engl. J. Med. 2013, 369, 2379-2390. [CrossRef] [PubMed]

13. Nangalia, J.; Massie, C.E.; Baxter, E.J.; Nice, F.L.; Gundem, G.; Wedge, D.C.; Avezov, E.; Li, J.; Kollmann, K.; Kent, D.G.; et al. Somatic CALR mutations in myeloproliferative neoplasms with nonmutated JAK2. N. Engl. J. Med. 2013, 369, 2391-2405. [CrossRef] [PubMed]

14. Pardanani, A.D.; Levine, R.L.; Lasho, T.; Pikman, Y.; Mesa, R.A.; Wadleigh, M.; Steensma, D.P.; Elliott, M.A.; Wolanskyj, A.P.; Hogan, W.J.; et al. MPL515 mutations in myeloproliferative and other myeloid disorders: A study of 1182 patients. Blood 2006, 108, 3472-3476. [CrossRef] [PubMed]

15. Pikman, Y.; Lee, B.H.; Mercher, T.; McDowell, E.; Ebert, B.L.; Gozo, M.; Cuker, A.; Wernig, G.; Moore, S.; Galinsky, I.; et al. MPLW515L is a novel somatic activating mutation in myelofibrosis with myeloid metaplasia. PLoS Med. 2006, 3, e270. [CrossRef] [PubMed]

16. Vainchenker, W.; Constantinescu, S.N. JAK/STAT signaling in hematological malignancies. Oncogene 2013, 32, 2601-2613. [CrossRef]

17. Chachoua, I.; Pecquet, C.; El-Khoury, M.; Nivarthi, H.; Albu, R.I.; Marty, C.; Gryshkova, V.; Defour, J.P.; Vertenoeil, G.; Ngo, A.; et al. Thrombopoietin receptor activation by myeloproliferative neoplasm associated calreticulin mutants. Blood 2016, 127, 1325-1335. [CrossRef]

18. Araki, M.; Yang, Y.; Masubuchi, N.; Hironaka, Y.; Takei, H.; Morishita, S.; Mizukami, Y.; Kan, S.; Shirane, S.; Edahiro, Y.; et al. Activation of the thrombopoietin receptor by mutant calreticulin in CALR-mutant myeloproliferative neoplasms. Blood 2016, 127, 1307-1316. [CrossRef] 
19. Elf, S.; Abdelfattah, N.S.; Chen, E.; Perales-Patón, J.; Rosen, E.A.; Ko, A.; Peisker, F.; Florescu, N.; Giannini, S.; Wolach, O.; et al. Mutant calreticulin requires both its mutant C-terminus and the thrombopoietin receptor for oncogenic transformation. Cancer Discov. 2016, 6, 368-381. [CrossRef]

20. Elf, S.; Abdelfattah, N.S.; Baral, A.J.; Beeson, D.; Rivera, J.F.; Ko, A.; Florescu, N.; Birrane, G.; Chen, E.; Mullally, A. Defining the requirements for the pathogenic interaction between mutant calreticulin and MPL in MPN. Blood 2018, 131, 782-786. [CrossRef]

21. Hansen, I.O.; Sørensen, A.L.; Hasselbalch, H.C. Second malignancies in hydroxyurea and interferon-treated Philadelphia-negative myeloproliferative neoplasms. Eur. J. Haematol. 2017, 98, 75-84. [CrossRef] [PubMed]

22. Silver, R.T.; Kiladjian, J.-J.; Hasselbalch, H.C. Interferon and the treatment of polycythaemia vera, essential thrombocytemia and myelofibrosis. Exp. Hematol. 2013, 6, 49-58. [CrossRef] [PubMed]

23. Larsen, T.S.; Møller, M.B.; de Stricker, K.; Nørgaard, P.; Samuelsson, J.; Marcher, C.; Andersen, M.T.; Bjerrum, O.W.; Hasselbalch, H.C. Minimal residual disease and normalization of the bone marrow after long-term treatment with alpha-interferon $2 \mathrm{~b}$ in polycythemia vera. A report on molecular response patterns in seven patients in sustained complete hematological remission. Hematology 2009, 14, 331-334. [CrossRef] [PubMed]

24. Kiladjian, J.-J.; Giraudier, S.; Cassinat, B. Interferon-alpha for the therapy of myeloproliferative neoplasms: Targeting the malignant clone. Leukemia 2015, 30, 776-781. [CrossRef] [PubMed]

25. Ostojic, A.; Vrhovac, R.; Verstovsek, S. Ruxolitinib: A new JAK1/2 inhibitor that offers promising options for treatment of myelofibrosis. Future Oncol. 2011, 7, 1035-1043. [CrossRef] [PubMed]

26. Vainchenker, W.; Leroy, E.; Gilles, L.; Marty, C.; Plo, I.; Constantinescu, S.N. JAK inhibitors for the treatment of myeloproliferative neoplasms and other disorders. F1000Research 2018, 7, 82. [CrossRef]

27. Verstovsek, S.; Mesa, R.A.; Gotlib, J.; Levy, R.S.; Gupta, V.; DiPersio, J.F.; Catalano, J.V.; Deininger, M.; Miller, C.; Silver, R.T.; et al. A double-blind, placebo-controlled trial of ruxolitinib for myelofibrosis. N. Engl. J. Med. 2012, 366, 799-807. [CrossRef]

28. Harrison, C.; Kiladjian, J.-J.; Al-Ali, H.K.; Gisslinger, H.; Waltzman, R.; Stalbovskaya, V.; McQuitty, M.; Hunter, D.S.; Levy, R.; Knoops, L.; et al. JAK Inhibition with Ruxolitinib versus Best Available Therapy for Myelofibrosis. N. Engl. J. Med. 2012, 366, 787-798. [CrossRef]

29. Cervantes, F.; Pereira, A. Does ruxolitinib prolong the survival of patients with myelofibrosis? Blood 2017, 129, 832-838. [CrossRef]

30. Deeg, H.J.; Gooley, T.A.; Flowers, M.E.D.; Sale, G.E.; Slattery, J.T.; Anasetti, C.; Chauncey, T.R.; Doney, K.; Georges, G.E.; Kiem, H.; et al. Allogeneic hematopoietic stem cell transplantation for myelofibrosis. Transplantation 2003, 102, 3912-3918. [CrossRef]

31. Barosi, G. An Immune Dysregulation in MPN. Curr. Hematol. Malig. Rep. 2014, 9, 331-339. [CrossRef] [PubMed]

32. Pourcelot, E.; Trocme, C.; Mondet, J.; Bailly, S.; Toussaint, B.; Mossuz, P. Cytokine profiles in polycythemia vera and essential thrombocythemia patients: Clinical implications. Exp. Hematol. 2014, 42, 360-368. [CrossRef] [PubMed]

33. Tefferi, A.; Vaidya, R.; Caramazza, D.; Finke, C.; Lasho, T.; Pardanani, A. Circulating Interleukin (IL)-8, IL-2R, IL-12, and IL-15 Levels Are Independently Prognostic in Primary Myelofibrosis: A Comprehensive Cytokine Profiling Study. J. Clin. Oncol. 2011, 29, 1356-1363. [CrossRef] [PubMed]

34. Bjørn, M.E.; Andersen, C.L.; Jensen, M.K.; Hasselbalch, H.C. Circulating YKL-40 in myelofibrosis a potential novel biomarker of disease activity and the inflammatory state. Eur. J. Haematol. 2014, 93, 224-228. [CrossRef]

35. Nina, A.Q.; Øbro, F.; Grinfeld, J.; Belmonte, M.; Irvine, M.; Shepherd, M.S.; Rao, T.N.; Karow, A.; Riedel, L.M.; Harris, O.B.; et al. Longitudinal Cytokine Pro fi ling Identi fi es GRO- a and EGF as Potential Biomarkers of Disease Progression in Essential Thrombocythemia. HemaSphere 2020, 4, e371.

36. Elli, E.M.; Baratè, C.; Mendicino, F.; Palandri, F.; Palumbo, G.A. Mechanisms Underlying the Anti-inflammatory and Immunosuppressive Activity of Ruxolitinib. Front. Oncol. 2019, 9, 1186. [CrossRef]

37. Hasselbalch, H.C. Perspectives on the impact of JAK-inhibitor therapy upon inflammation-mediated comorbidities in myelofibrosis and related neoplasms. Expert Rev. Hematol. 2014, 7, 203-216. [CrossRef]

38. Kristinsson, S.Y.; Landgren, O.; Samuelsson, J.; Björkholm, M.; Goldin, L.R. Autoimmunity and the risk of myeloproliferative neoplasms. Haematologica 2010, 95, 1216-1220. [CrossRef] 
39. Bak, M.; Sørensen, T.L.; Flachs, E.M.; Zwisler, A.D.; Juel, K.; Frederiksen, H.; Hasselbalch, H.C. Age-related macular degeneration in patients with chronic myeloproliferative neoplasms. JAMA Ophthalmol. 2017, 135, 835-843. [CrossRef] [PubMed]

40. Hasselbalch, H.C. Perspectives on chronic inflammation in essential thrombocythemia, polycythemia vera, and myelofibrosis: Is chronic inflammation a trigger and driver of clonal evolution and development of accelerated atherosclerosis and second cancer? Blood 2012, 119, 3219-3225. [CrossRef]

41. Hasselbalch, H.C. Chronic inflammation as a promotor of mutagenesis in essential thrombocythemia, polycythemia vera and myelofibrosis. A human inflammation model for cancer development? Leuk. Res. 2013, 37, 214-220. [CrossRef] [PubMed]

42. Greten, F.R.; Grivennikov, S.I. Inflammation and Cancer: Triggers, Mechanisms, and Consequences. Immunity 2019, 51, 27-41. [CrossRef]

43. Coussens, L.M.; Werb, Z.; Coussens, L.M.; Werb, Z. Inflammation and cancer. Nature 2002, 420, 860-867. [CrossRef] [PubMed]

44. Cervantes, F.; Hernández-Boluda, J.C.; Villamor, N.; Serra, A.; Montserrat, E. Assessment of peripheral blood lymphocyte subsets in idiopathic myelofibrosis. Eur. J. Haematol. 2000, 65, 104-108. [CrossRef] [PubMed]

45. Elliott, M.A.; Verstovsek, S.; Dingli, D.; Schwager, S.M.; Mesa, R.A.; Li, C.Y.; Tefferi, A. Monocytosis is an adverse prognostic factor for survival in younger patients with primary myelofibrosis. Leuk. Res. 2007, 31, 1503-1509. [CrossRef]

46. Barraco, D.; Cerquozzi, S.; Gangat, N.; Patnaik, M.M.; Lasho, T.; Finke, C.; Hanson, C.A.; Ketterling, R.P.; Pardanani, A.; Tefferi, A. Monocytosis in polycythemia vera: Clinical and molecular correlates. Am. J. Hematol. 2017, 92, 640-645. [CrossRef]

47. Riley, C.H.; Hansen, M.; Brimnes, M.K.; Hasselbalch, H.C.; Bjerrum, O.W.; Straten, P.T.; Svane, I.M.; Jensen, M.K. Expansion of circulating CD56(bright) natural killer cells in patients with JAK2-positive chronic myeloproliferative neoplasms during treatment with interferon- $\alpha$. Eur. J. Haematol. 2015, 94, 227-234. [CrossRef]

48. Shakil, S.; Chen, C.; Surahio, A.; Mirza, M.; Su, M.; Sun, Y.; Wang, J.-C. T Regulator Cells (Treg) In Patients with Myelofibrosis. ASH Annu. Meet. Abstr. 2010, 116, 5051. [CrossRef]

49. Riley, C.H.; Jensen, M.K.; Brimnes, M.K.; Hasselbalch, H.C.; Bjerrum, O.W.; Straten, P.T.; Svane, I.M. Increase in circulating $\mathrm{CD}^{+} \mathrm{CD} 25^{+} \mathrm{Foxp}^{+} \mathrm{T}$ cells in patients with Philadelphia-negative chronic myeloproliferative neoplasms during treatment with IFN- $\alpha$. Blood 2011, 118, 2170-2173. [CrossRef]

50. Keohane, C.; Kordasti, S.; Seidl, T.; Perez Abellan, P.; Thomas, N.S.B.; Harrison, C.N.; Mclornan, D.P.; Mufti, G.J. JAK inhibition induces silencing of T Helper cytokine secretion and a profound reduction in T regulatory cells. Br. J. Haematol. 2015, 171, 60-73. [CrossRef]

51. Ostrand-Rosenberg, S.; Sinha, P. Myeloid-Derived Suppressor Cells: Linking Inflammation and Cancer. J. Immunol. 2009, 182, 4499-4506. [CrossRef] [PubMed]

52. Gabrilovich, D.I.; Nagaraj, S. Myeloid-derived suppressor cells as regulators of the immune system. Nat. Rev. Immunol. 2009, 9, 162-174. [CrossRef] [PubMed]

53. Wang, J.C.; Kundra, A.; Andrei, M.; Baptiste, S.; Chen, C.; Wong, C. Myeloid-derived suppressor cells in patients with myeloproliferative neoplasm. Leuk. Res. 2016, 43, 39-43. [CrossRef] [PubMed]

54. Baptiste, S.; Chen, C.; Sindhu, H.; Wang, J.-C. Programmed Cell Death Receptor (PD-1), PD-1 Ligand (PD-L1) Expression and Myeloid Derived Suppressor Cells (MDSC) In Myeloid Neoplasms Implicate The Mechanism Of IMiD Treatment Of Myelofibrosis. Blood 2013, 122, 2837.

55. Larsen, T.S.; Christensen, J.H.; Hasselbalch, H.C.; Pallisgaard, N. The JAK2 V617F mutation involves Band T-lymphocyte lineages in a subgroup of patients with Philadelphia-chromosome negative chronic myeloproliferative disorders. Br. J. Haematol. 2007, 136, 745-751. [CrossRef] [PubMed]

56. Kjaer, L.; Holmström, M.O.; Cordua, S.; Thomassen, M.; Kruse, T.A.; Andersen, M.H.; Svane, I.M.; Pallisgaard, N.; Skov, V.; Hasselbalch, H.C. Sorted Peripheral Blood Cells Identify CALR Mutations in B- and T-lymphocytes. Leuk. Lymphoma 2017, 59, 973-977. [CrossRef]

57. Raghavan, M.; Wijeyesakere, S.J.; Peters, L.R.; Del Cid, N. Calreticulin in the immune system: Ins and outs. Trends Immunol. 2013, 34, 13-21. [CrossRef]

58. Ward, A.C.; Touw, I.; Yoshimura, A. Review article The Jak-Stat pathway in normal and perturbed hematopoiesis. Blood J. Am. Soc. Hematol. 2016, 95, 19-30. 
59. Dupuis, B.M.; Schaerer, E.; Krause, K.; Tschopp, J. The Calcium-binding Protein Calreticulin Is a Major Constituent of Lytic Granules in Cytolytic T Lymphocytes. J. Exp. Med. 1993, 177, 1-7. [CrossRef] [PubMed]

60. Sipione, S.; Ewen, C.; Shostak, I.; Bleackley, R.C.; Sipione, S.; Ewen, C.; Shostak, I.; Michalak, M.; Bleackley, R.C. Impaired cytolytic activity in calreticulin-deficient CTLs. J. Immunol. 2005, 174, 3212-3219. [CrossRef] [PubMed]

61. Andrin, C.; Pinkoski, M.J.; Burns, K.; Atkinson, E.A.; Krahenbuhl, O.; Hudig, D.; Fraser, S.A.; Winkler, U.; Tschopp, J.; Opas, M.; et al. Interaction between a $\mathrm{Ca}^{2+}$-binding protein calreticulin and perforin, a component of the cytotoxic T-cell granules. Biochemistry 1998, 37, 10386-10394. [CrossRef] [PubMed]

62. Porcellini, S.; Traggiai, E.; Schenk, U.; Ferrera, D.; Matteoli, M.; Lanzavecchia, A.; Michalak, M.; Grassi, F. Regulation of peripheral T cell activation by calreticulin. J. Exp. Med. 2006, 203, 461-471. [CrossRef] [PubMed]

63. Rameshwar, P.; Denny, T.N.; Stein, D.; Gascón, P.; Rameshwar, P.; Denny, T.N.; Stein, D.; Gascon, P. Monocyte adhesion in patients with bone marrow fibrosis is required for the production of fibrogenic cytokines. Potential role for interleukin-1 and TGF-beta. J. Immunol. 1994, 153, 2819-2830. [PubMed]

64. Cardoso, E.M.; Esgalhado, A.J.; Patrão, L.; Santos, M.; Neves, V.P.; Martinez, J. Distinctive CD8 ${ }^{+}$T cell and MHC class I signatures in polycythemia vera patients. Ann. Hematol. 2018, 97, 1563-1575. [CrossRef]

65. Skov, V.; Riley, C.H.; Thomassen, M.; Larsen, T.S.; Jensen, M.K.; Bjerrum, O.W.; Kruse, T.A.; Hasselbalch, H.C. Whole blood transcriptional profiling reveals significant down-regulation of human leukocyte antigen class I and II genes in essential thrombocythemia, polycythemia vera and myelofibrosis. Leuk. Lymphoma 2013, 54, 2269-2273. [CrossRef]

66. Skov, V.; Thomassen, M.; Riley, C.H.; Jensen, M.K.; Bjerrum, O.W.; Kruse, T.A.; Hasselbalch, H.C.; Larsen, T.S. Gene expression profiling with principal component analysis depicts the biological continuum from essential thrombocythemia over polycythemia vera to myelofibrosis. Exp. Hematol. 2012, 40, 771-780.e19. [CrossRef]

67. Skov, V.; Larsen, T.S.; Thomassen, M.; Riley, C.H.; Jensen, M.K.; Bjerrum, O.W.; Kruse, T.A.; Hasselbalch, H.C. Molecular profiling of peripheral blood cells from patients with polycythemia vera and related neoplasms: Identification of deregulated genes of significance for inflammation and immune surveillance. Leuk. Res. 2012, 36, 1387-1392. [CrossRef]

68. Romano, M.; Sollazzo, D.; Trabanelli, S.; Barone, M.; Polverelli, N.; Perricone, M.; Forte, D.; Luatti, S.; Cavo, M.; Vianelli, N.; et al. Mutations in JAK2 and Calreticulin genes are associated with specific alterations of the immune system in myelofibrosis. Oncoimmunology 2017, 6, e1345402. [CrossRef]

69. Prestipino, A.; Emhardt, A.J.; Aumann, K.; Sullivan, D.O.; Gorantla, S.P.; Duquesne, S.; Melchinger, W.; Braun, L.; Boerries, M.; Busch, H.; et al. Oncogenic JAK2 V617F causes PD-L1 expression, mediating immune escape in myeloproliferative neoplasms. Sci. Transl. Med. 2018, 10, eaam7729. [CrossRef]

70. Wang, J.C.; Chen, C.; Kundra, A.; Kodali, S.; Pandey, A.; Wong, C.; Cheung, T.; Gotlieb, V.; Joseph, G.; Tribie, S. Programmed Cell Death Receptor (PD-1) Ligand (PD-L1) expression in Philadelphia chromosome-negative myeloproliferative neoplasms. Leuk. Res. 2019, 79, 52-59. [CrossRef]

71. Bozkus, C.C.; Roudko, V.; Finnigan, J.P.; Mascarenhas, J.; Hoffman, R.; Iancu-rubin, C.; Bhardwaj, N. Immune Checkpoint Blockade Enhances Shared Neoantigen-Induced T-cell Immunity Directed against Mutated Calreticulin in Myeloproliferative Neoplasms. Cancer Discov. 2019, 9, 1192-1207. [CrossRef] [PubMed]

72. Zhang, X.; Lv, Z.; Yu, H.; Zhu, J. The clinicopathological and prognostic role of thrombocytosis in patients with cancer: A meta-analysis. Oncol. Lett. 2017, 13, 5002-5008. [CrossRef]

73. Hasselbalch, H.C. The platelet-cancer loop in myeloproliferative cancer. Is thrombocythemia an enhancer of cancer invasiveness and metastasis in essential thrombocythemia, polycythemia vera and myelofibrosis? Leuk. Res. 2014, 38, 1230-1236. [CrossRef] [PubMed]

74. Rachidi, S.; Metelli, A.; Riesenberg, B.; Wu, B.X.; Nelson, M.H.; Wallace, C.; Paulos, C.M.; Rubinstein, M.P.; Garrett-Mayer, E.; Hennig, M.; et al. Platelets subvert T cell immunity against cancer via GARP-TGF $\beta$ axis. Sci. Immunol. 2017, 2, eaai7911. [CrossRef]

75. Marty, C.; Lacout, C.; Droin, N.; Le Couédic, J.-P.; Ribrag, V.; Solary, E.; Vainchenker, W.; Villeval, J.-L.; Plo, I. A role for reactive oxygen species in JAK2V617F myeloproliferative neoplasm progression. Leukemia 2013, 27, 2187-2195. [CrossRef]

76. Belikov, A.V.; Schraven, B.; Simeoni, L. T cells and reactive oxygen species. J. Biomed. Sci. 2015, $22,85$. [CrossRef] [PubMed] 
77. Chen, X.; Song, M.; Zhang, B.; Zhang, Y. Reactive Oxygen Species Regulate T Cell Immune Response in the Tumor Microenvironment. Oxid. Med. Cell. Longev. 2016, 2016, 11-16. [CrossRef]

78. Arshad, N.; Cresswell, P. Tumor-associated calreticulin variants functionally compromise the peptide loading complex and impair its recruitment of MHC-I. J. Biol. Chem. 2018, 293, 9555-9569. [CrossRef]

79. Sollazzo, D.; Forte, D.; Polverelli, N.; Perricone, M.; Romano, M.; Luatti, S.; Vianelli, N.; Cavo, M.; Palandri, F.; Catani, L. Circulating Calreticulin Is Increased in Myelofibrosis: Correlation with Interleukin-6 Plasma Levels, Bone Marrow Fibrosis, and Splenomegaly. Mediat. Inflamm. 2016, 2016, 5860657. [CrossRef]

80. Han, L.; Schubert, C.; Köhler, J.; Schemionek, M.; Isfort, S.; Brümmendorf, T.H.; Koschmieder, S.; Chatain, N. Calreticulin-mutant proteins induce megakaryocytic signaling to transform hematopoietic cells and undergo accelerated degradation and Golgi-mediated secretion. J. Hematol. Oncol. 2016, 9, 45. [CrossRef]

81. Garbati, M.R.; Welgan, C.A.; Landefeld, S.H.; Newell, L.F.; Agarwal, A.; Dunlap, J.B.; Chourasia, T.K.; Lee, H.; Elferich, J.; Traer, E.; et al. Mutant calreticulin-expressing cells induce monocyte hyperreactivity through a paracrine mechanism. Am. J. Hematol. 2016, 91, 211-219. [CrossRef] [PubMed]

82. Liu, P.; Zhao, L.; Loos, F.; Marty, C.; Xie, W.; Martins, I.; Lachkar, S.; Qu, B.; Waeckel-Énée, E.; Plo, I.; et al. Immunosuppression by Mutated Calreticulin Released from Malignant Cells Article Immunosuppression by Mutated Calreticulin Released from Malignant Cells. Mol. Cell 2020, 77, 748-760. [CrossRef] [PubMed]

83. Kroemer, G.; Galluzzi, L.; Kepp, O.; Zitvogel, L. Immunogenic cell death in cancer therapy. Annu. Rev. Immunol. 2013, 31, 51-72. [CrossRef] [PubMed]

84. Holmström, M.O.; Riley, C.H.; Svane, I.M.; Hasselbalch, H.C.; Andersen, M.H. The CALR exon 9 mutations are shared neoantigens in patients with CALR mutant chronic myeloproliferative neoplasms. Leukemia 2016, 30, 2413-2416. [CrossRef] [PubMed]

85. Holmstrom, M.O.; Martinenaite, E.; Ahmad, S.M.; Met, O.; Friese, C.; Kjaer, L.; Riley, C.H.; thor Straten, P.; Svane, I.M.; Hasselbalch, H.C.; et al. The calreticulin (CALR) exon 9 mutations are promising targets for cancer immune therapy. Leukemia 2018, 32, 429-437. [CrossRef] [PubMed]

86. Dunn, G.P.; Old, L.J.; Schreiber, R.D. The Three Es of Cancer Immunoediting. Annu. Rev. Immunol. 2004, 22, 329-360. [CrossRef] [PubMed]

87. Holmström, M.O.; Ahmad, S.M.; Klausen, U.; Bendtsen, S.K.; Martinenaite, E.; Riley, C.H.; Svane, I.M.; Kjær, L.; Skov, V.; Ellervik, C.; et al. High frequencies of circulating memory T cells specific for calreticulin exon 9 mutations in healthy individuals. Blood Cancer J. 2019, 9, 8. [CrossRef]

88. Tubb, V.M.; Schrikkema, D.S.; Croft, N.P.; Purcell, A.W.; Linnemann, C.; Freriks, M.R.; Chen, F.; Long, H.M.; Lee, S.P.; Bendle, G.M. Isolation of T cell receptors targeting recurrent neoantigens in hematological malignancies. J. Immunother. Cancer 2018, 6, 70. [CrossRef]

89. Cordua, S.; Kjaer, L.; Skov, V.; Pallisgaard, N.; Hasselbalch, H.C.; Ellervik, C. Prevalence and phenotypes of JAK2 V617F and Calreticulin mutations in a Danish general population. Blood 2019, 134, 469-479. [CrossRef]

90. Holmström, M.O.; Cordua, S.; Skov, V.; Kjær, L.; Pallisgaard, N.; Ellervik, C.; Hasselbalch, H.C.; Hald Andersen, M. Evidence of immune elimination, immuno-editing and immune escape in patients with hematological cancer. Cancer Immunol. Immunother. 2020, 69, 315-324. [CrossRef]

91. Dunn, G.P.; Bruce, A.T.; Ikeda, H.; Old, L.J.; Schreiber, R.D. Cancer immunoediting: From immunosurveillance to tumor escape. Nat. Immunol. 2002, 3, 991-998. [CrossRef] [PubMed]

92. Pettersson, H.; Knutsen, H.; Holmberg, E.; Andréasson, B. Increased incidence of another cancer in myeloproliferative neoplasms patients at the time of diagnosis. Eur. J. Haematol. 2014, 94, 152-156. [CrossRef] [PubMed]

93. Landtblom, A.R.; Bower, H.; Andersson, T.M.-L.; Dickman, P.W.; Samuelsson, J.; Björkholm, M.; Kristinsson, S.Y.; Hultcrantz, M. Second malignancies in patients with myeloproliferative neoplasms: A population-based cohort study of 9379 patients. Leukemia 2018, 32, 2203-2210. [CrossRef] [PubMed]

94. Frederiksen, H.; Farkas, D.K.; Christiansen, C.F.; Hasselbalch, H.C.; Sørensen, H.T.; Sorensen, H.T. Chronic myeloproliferative neoplasms and subsequent cancer risk: A Danish population-based cohort study. Blood 2011, 118, 6515-6520. [CrossRef] [PubMed]

95. Zitvogel, L.; Galluzzi, L.; Kepp, O.; Smyth, M.J.; Kroemer, G. Type I interferons in anticancer immunity. Nat. Rev. Immunol. 2015, 15, 405-414. [CrossRef] [PubMed]

96. Parker, B.S.; Rautela, J.; Hertzog, P.J. Antitumour actions of interferons: Implications for cancer therapy. Nat. Rev. Cancer 2016, 16, 131-144. [CrossRef] 
97. Minn, A.J. Interferons and the Immunogenic Effects of Cancer Therapy. Trends Immunol. 2015, 36, 725-737. [CrossRef]

98. Schiavoni, G.; Mattei, F.; Gabriele, L. Type I interferons as stimulators of DC-mediated cross-priming: Impact on anti-tumor response. Front. Immunol. 2013, 4, 483. [CrossRef]

99. Bracci, L.; Proietti, E.; Belardelli, F. IFN-alpha and novel strategies of combination therapy for cancer. Ann. N. Y. Acad. Sci. 2007, 1112, 256-268. [CrossRef]

100. Hasselbalch, H.C.; Larsen, T.S.; Riley, C.H.; Jensen, M.K.; Kiladjian, J.-J. Interferon-alpha in the treatment of Philadelphia-negative chronic myeloproliferative neoplasms. Status and perspectives. Curr. Drug Targets 2011, 12, 392-419. [CrossRef]

101. Cassinat, B.; Verger, E.; Kiladjian, J.-J. Interferon Alfa Therapy in CALR-Mutated Essential Thrombocythemia. N. Engl. J. Med. 2014, 371, 188-189. [CrossRef] [PubMed]

102. Kjær, L.; Cordua, S.; Holmström, M.O.; Thomassen, M.; Kruse, T.A.; Pallisgaard, N.; Larsen, T.S.; de Stricker, K.; Skov, V.; Hasselbalch, H.C. Differential Dynamics of CALR Mutant Allele Burden in Myeloproliferative Neoplasms during Interferon Alfa Treatment. PLoS ONE 2016, 11, e0165336. [CrossRef] [PubMed]

103. Riley, C.H.; Brimnes, M.K.; Hansen, M.; Jensen, M.K.; Hasselbalch, H.C.; Kjaer, L.; Straten, P.T.; Svane, I.M. Interferon- $\alpha$ induces marked alterations in circulating regulatory $\mathrm{T}$ cells, NK cell subsets, and dendritic cells in patients with JAK2V617F-positive essential thrombocythemia and polycythemia vera. Eur. J. Haematol. 2016, 97, 83-92. [CrossRef] [PubMed]

104. Skov, V.; Riley, C.H.; Thomassen, M.; Kjær, L.; Larsen, T.S.; Bjerrum, O.W.; Kruse, T.A.; Hasselbalch, H.C. The impact of interferon-alpha2 on HLA genes in patients with polycythemia vera and related neoplasms. Leuk. Lymphoma 2016, 58, 1914-1921. [CrossRef] [PubMed]

105. Kovacsovics-Bankowski, M.; Kelley, T.W.; Efimova, O.; Kim, S.J.; Wilson, A.; Swierczek, S.; Prchal, J. Changes in peripheral blood lymphocytes in polycythemia vera and essential thrombocythemia patients treated with pegylated-interferon alpha and correlation with JAK2 V617F allelic burden. Exp. Hematol. Oncol. 2015, 5, 28. [CrossRef]

106. Coulie, P.G.; Van den Eynde, B.J.; van der Bruggen, P.; Boon, T. Tumour antigens recognized by T lymphocytes: At the core of cancer immunotherapy. Nat. Rev. Cancer 2014, 14, 135-146. [CrossRef]

107. Schumacher, T.N.; Schreiber, R.D. Neoantigens in cancer immunotherapy. Science 2015, 348, 69-74. [CrossRef]

108. Holmström, M.O.; Hjortsø, M.D.; Ahmad, S.M.; Met, Ö.; Martinenaite, E.; Riley, C.; Straten, P.; Svane, I.M.; Hasselbalch, H.C.; Andersen, M.H. The JAK2V617F mutation is a target for specific T cells in the JAK2V617F-positive myeloproliferative neoplasms. Leukemia 2017, 31, 495-498. [CrossRef]

109. Schischlik, F.; Jäger, R.; Rosebrock, F.; Hug, E.; Schuster, M.K.; Holly, R.; Fuchs, E.; Milosevic Feenstra, J.D.; Bogner, E.; Gisslinger, B.; et al. Mutational Landscape of the Transcriptome Offers Putative Targets for Immunotherapy of Myeloproliferative Neoplasms. Blood 2019, 134, 199-210. [CrossRef]

110. Posthuma, E.F.; Falkenburg, J.H.; Apperley, J.F.; Gratwohl, A.; Roosnek, E.; Hertenstein, B.; Schipper, R.F.; Schreuder, G.M.; D'Amaro, J.; Oudshoorn, M.; et al. HLA-B8 and HLA-A3 coexpressed with HLA-B8 are associated with a reduced risk of the development of chronic myeloid leukemia. The Chronic Leukemia Working Party of the EBMT. Blood 1999, 93, 3863-3865.

111. Kuželová, K.; Brodská, B.; Fuchs, O.; Dobrovolná, M.; Soukup, P.; Cetkovský, P. Altered HLA class I profile associated with type A/D nucleophosmin mutation points to possible anti-nucleophosmin immune response in acute myeloid leukemia. PLoS ONE 2015, 10, e0127637. [CrossRef] [PubMed]

112. Rusakiewicz, S.; Madrigal, A.; Travers, P.; Dodi, A.I. BCR/ABL-specific CD8 ${ }^{+} \mathrm{T}$ cells can be detected from CML patients, but are only expanded from healthy donors. Cancer Immunol. Immunother. 2009, 58, 1449-1457. [CrossRef] [PubMed]

113. Greiner, J.; Ono, Y.; Hofmann, S.; Schmitt, A.; Mehring, E.; Götz, M.; Guillaume, P.; Döhner, K.; Mytilineos, J.; Döhner, H.; et al. Mutated regions of nucleophosmin 1 elicit both $\mathrm{CD}^{+}{ }^{+}$and $\mathrm{CD} 8{ }^{+} \mathrm{T}$-cell responses in patients with acute myeloid leukemia. Blood 2016, 97, 1282-1290. [CrossRef] [PubMed]

114. Freeman, G.J.; Long, A.J.; Iwai, Y.; Bourque, K.; Chernova, T.; Nishimura, H.; Fitz, L.J.; Malenkovich, N.; Okazaki, T.; Byrne, M.C.; et al. Engagement of the PD-1 immunoinhibitory receptor by a novel B7 family member leads to negative regulation of lymphocyte activation. J. Exp. Med. 2000, 192, 1027-1034. [CrossRef]

115. Ribas, A. Adaptive immune resistance: How cancer protects from immune attack. Cancer Discov. 2015, 5, 915-919. [CrossRef] 
116. Wolchok, J.D.; Kluger, H.; Callahan, M.K.; Postow, M.A.; Rizvi, N.A.; Lesokhin, A.M.; Segal, N.H.; Ariyan, C.E.; Gordon, R.-A.; Reed, K.; et al. Nivolumab plus ipilimumab in advanced melanoma. N. Engl. J. Med. 2013, 369, 122-133. [CrossRef]

117. Garon, E.B.; Rizvi, N.A.; Hui, R.; Leighl, N.; Balmanoukian, A.S.; Eder, J.P.; Patnaik, A.; Aggarwal, C.; Gubens, M.; Horn, L.; et al. Pembrolizumab for the treatment of non-small-cell lung cancer. N. Engl. J. Med. 2015, 372, 2018-2028. [CrossRef]

118. Ansell, S.M.; Lesokhin, A.M.; Borrello, I.; Halwani, A.; Scott, E.C.; Gutierrez, M.; Schuster, S.J.; Millenson, M.M.; Cattry, D.; Freeman, G.J.; et al. PD-1 Blockade with Nivolumab in Relapsed or Refractory Hodgkin's Lymphoma. N. Engl. J. Med. 2014, 372, 311-319. [CrossRef]

119. Goodman, A.; Patel, S.P.; Kurzrock, R. PD-1-PD-L1 immune-checkpoint blockade in B-cell lymphomas. Nat. Rev. Clin. Oncol. 2017, 14, 203-220. [CrossRef]

120. Liu, J.; Hamrouni, A.; Wolowiec, D.; Rie Coiteux, V.; Kuliczkowski, K.; Hetuin, D.; Saudemont, A.; Quesnel, B. Plasma cells from multiple myeloma patients express B7-H1 (PD-L1) and increase expression after stimulation with IFN-and TLR ligands via a MyD88-, TRAF6-, and MEK-dependent pathway. Blood 2007, 110, $296-304$. [CrossRef]

121. Schnorfeil, F.M.; Lichtenegger, F.S.; Emmerig, K.; Schlueter, M.; Neitz, J.S.; Draenert, R.; Hiddemann, W.; Subklewe, M. T cells are functionally not impaired in AML: Increased PD-1 expression is only seen at time of relapse and correlates with a shift towards the memory T cell compartment. J. Hematol. Oncol. 2015, 8, 93. [CrossRef] [PubMed]

122. Yang, H.; Bueso-Ramos, C.; DiNardo, C.; Estecio, M.R.; Davanlou, M.; Geng, Q.-R.; Fang, Z.; Nguyen, M.; Pierce, S.; Wei, Y.; et al. Expression of PD-L1, PD-L2, PD-1 and CTLA4 in myelodysplastic syndromes is enhanced by treatment with hypomethylating agents. Leukemia 2014, 28, 1280-1288. [CrossRef] [PubMed]

123. Ørskov, A.D.; Treppendahl, M.B.; Skovbo, A.; Holm, M.S.; Friis, L.S.; Hokland, M.; Grønbæk, K. Hypomethylation and up-regulation of PD-1in T cells by azacytidine in MDS/AML patients: A rationale for combined targeting of PD-1 and DNA methylation. Oncotarget 2015, 6, 9612-9626. [CrossRef] [PubMed]

124. Ravandi-Kashani, F.; Garcia-Manero, G.; Ning, J.; Alhamal, Z.; DiNardo, C.D.; Pierce, S.A.; Pemmaraju, N.; Patel, K.P.; Blando, J.; Alfayez, M.; et al. Efficacy, Safety, and Biomarkers of Response to Azacitidine and Nivolumab in Relapsed/Refractory Acute Myeloid Leukemia: A Non-randomized, Open-label, Phase 2 Study. Cancer Discov. 2018, 9, 370-383.

125. Spiers, L.; Coupe, N.; Payne, M. Toxicities associated with checkpoint inhibitors-An overview. Rheumatology (UK) 2019, 58, vii7-vii16. [CrossRef]

126. Munir, S.; Larsen, S.K.; Iversen, T.Z.; Donia, M.; Klausen, T.W.; Svane, I.M.; thor Straten, P.; Andersen, M.H. Natural CD4 ${ }^{+}$T-cell responses against indoleamine 2,3-dioxygenase. PLoS ONE 2012, 7, e34568. [CrossRef]

127. Sørensen, R.B.; Køllgaard, T.; Andersen, R.S.; Van Den Berg, J.H.; Svane, I.M.; Straten, P.T.; Andersen, M.H. Spontaneous cytotoxic T-cell reactivity against indoleamine 2,3-dioxygenase-2. Cancer Res. 2011, 71, 2038-2044. [CrossRef]

128. Munir, S.; Andersen, G.H.; Met, Ö.; Donia, M.; Frøsig, T.M.; Larsen, S.K.; Klausen, T.W.; Svane, I.M.; Andersen, M.H. HLA-restricted CTL that are specific for the immune checkpoint ligand PD-L1 occur with high frequency in cancer patients. Cancer Res. 2013, 73, 1764-1776. [CrossRef]

129. Munir, S.; Andersen, G.H.; Svane, I.M.; Andersen, M.H. The immune checkpoint regulator PD-L1 is a specific target for naturally occurring CD4 ${ }^{+} \mathrm{T}$ cells. Oncoimmunology 2013, 2, e23991. [CrossRef]

130. Ahmad, S.M.; Svane, I.M.; Andersen, M.H. The stimulation of PD-L1-specific cytotoxic T lymphocytes can both directly and indirectly enhance antileukemic immunity. Blood Cancer J. 2014, 4, e230. [CrossRef]

131. Munir Ahmad, S.; Martinenaite, E.; Hansen, M.; Junker, N.; Borch, T.H.; Met, Ö.; Donia, M.; Svane, I.M.; Andersen, M.H. PD-L1 peptide co-stimulation increases immunogenicity of a dendritic cell-based cancer vaccine. Oncoimmunology 2016, 5, e1202391. [CrossRef] [PubMed]

132. Andersen, M.H. Anti-regulatory T cells. Semin. Immunopathol. 2017, 39, 317-326. [CrossRef] [PubMed]

133. Holmström, M.O.; Riley, C.H.; Skov, V.; Svane, I.M.; Hasselbalch, H.C.; Andersen, M.H. Spontaneous T-cell responses against the immune check point programmed-death-ligand 1 (PD-L1) in patients with chronic myeloproliferative neoplasms correlate with disease stage and clinical response. Oncoimmunology 2018, 7, e1433521. [CrossRef] [PubMed] 
134. Aaboe-Jørgensen, M.; Holmström, M.O.; Martinenaite, E.; Riley, C.H.; Hasselbalch, H.C.; Hald Andersen, M. Spontaneous T-cell responses against Arginase-1 in chronic myeloproliferative neoplasms relative to disease stage and type of driver mutation. Oncoimmunology 2018, 7, e1468957. [CrossRef]

135. Qazilbash, M.H.; Wieder, E.; Thall, P.F.; Wang, X.; Rios, R.; Lu, S.; Kanodia, S.; Ruisaard, K.E.; Giralt, S.A.; Estey, E.H.; et al. PR1 peptide vaccine induces specific immunity with clinical responses in myeloid malignancies. Leukemia 2017, 31, 697-704. [CrossRef]

136. Melief, C.J.M.; van Hall, T.; Arens, R.; Ossendorp, F.; van der Burg, S.H. Therapeutic cancer vaccines. J. Clin. Investig. 2015, 125, 3401-3412. [CrossRef]

137. Restifo, N.P.; Dudley, M.E.; Rosenberg, S. a Adoptive immunotherapy for cancer: Harnessing the T cell response. Nat. Rev. Immunol. 2012, 12, 269-281. [CrossRef]

138. Goebeler, M.-E.; Knop, S.; Viardot, A.; Kufer, P.; Topp, M.S.; Einsele, H.; Noppeney, R.; Hess, G.; Kallert, S.; Mackensen, A.; et al. Bispecific T-Cell Engager (BiTE) Antibody Construct Blinatumomab for the Treatment of Patients With Relapsed/Refractory Non-Hodgkin Lymphoma: Final Results From a Phase I Study. J. Clin. Oncol. 2016, 34, 1104-1111. [CrossRef]

139. Blanc, C.; Granier, C.; Saldmann, A.; Tanchot, C.; Tartour, E.; Tran, T. Therapeutic cancer vaccine: Building the future from lessons of the past. Semin. Immunopathol. 2018, 41, 69-85.

140. Krysko, D.V.; Garg, A.D.; Kaczmarek, A.; Krysko, O.; Agostinis, P.; Vandenabeele, P. Immunogenic cell death and DAMPs in cancer therapy. Nat. Rev. Cancer 2012, 12, 860-875. [CrossRef]

141. Obeid, M.; Tesniere, A.; Ghiringhelli, F.; Fimia, G.M.; Apetoh, L.; Perfettini, J.-L.; Castedo, M.; Mignot, G.; Panaretakis, T.; Casares, N.; et al. Calreticulin exposure dictates the immunogenicity of cancer cell death. Nat. Med. 2007, 13, 54-61. [CrossRef] [PubMed]

142. Obeid, M.; Tesniere, A.; Panaretakis, T.; Tufi, R.; Joza, N.; Van Endert, P.; Ghiringhelli, F.; Apetoh, L.; Chaput, N.; Flament, C.; et al. Ecto-calreticulin in immunogenic chemotherapy. Immunol. Rev. 2007, 220, 22-34. [CrossRef] [PubMed]

(C) 2020 by the authors. Licensee MDPI, Basel, Switzerland. This article is an open access article distributed under the terms and conditions of the Creative Commons Attribution (CC BY) license (http://creativecommons.org/licenses/by/4.0/). 